This PDF is a selection from a published volume from the National Bureau of Economic Research

Volume Title: International Differences in the Business Practices and Productivity of Firms

Volume Author/Editor: Richard B. Freeman and Kathryn L. Shaw, editors

Volume Publisher: University of Chicago Press

Volume ISBN: 0-226-26194-8

Volume URL: http://www.nber.org/books/free07-1

Conference Date: January 2006

Publication Date: September 2009

Chapter Title: Measuring the Productivity of Software Development in a Globally Distributed Company

Chapter Author: Alec Levenson

Chapter URL: http://www.nber.org/chapters/c0440

Chapter pages in book: (p. 193 - 230) 


\title{
Measuring the Productivity of Software Development in a Globally Distributed Company
}

\author{
Alec Levenson
}

\subsection{Introduction}

The trend toward outsourcing outside of manufacturing, which has been emblazoned in the newspaper headlines and magazine covers in recent years, started with software development. Long before there were reports about accounting and research and development (R\&D) jobs moving from the United States to developing countries such as India and China, software was the story. The predominant reason for the movement of such knowledge work jobs, including software-related, is labor costs. With large and growing numbers of highly educated and technically adept scientists and engineers in low labor cost countries, and plummeting costs for high speed telecommunications infrastructure that allows for instantaneous communication around the globe, the allure of being able to develop and produce the same product at lower costs has been too tempting for many companies to resist.

This chapter analyzes the experience of one company that has moved extensively to take advantage of lower labor costs for technical talent by spreading its software R\&D work worldwide. The research issues addressed are (a) whether there are differences in performance between the company's software development sites in the United States, Western Europe, and other countries; (b) the factors leading to those differences; (c) the company's rationale for locating software development work in those locations; and (d) the future prospects for software development work at those locations.

Alec Levenson is a research scientist at the Center for Effective Organizations of the University of Southern California.

The author would like to thank Nora Osganian for excellent research assistance, and participants at the NBER Summer Institute for helpful comments. Funding for the research was provided by the Sloan Foundation. 
The motivation for the research comes from the Sloan Foundation's desire to better understand productivity differences in the United States and Western Europe. After focusing on economy-wide and industry-wide differences in productivity that have left many questions unanswered, the current focus is on within-company differences: comparing two sites within the same organization that produce similar outputs on different continents, are there productivity differences and, if so, why? The company in question has sites in both the United States and France, and thus appeared to be an ideal candidate for studying such differences.

In the case of software development, the work that is done at "remote" sites (i.e., away from the headquarters of a company) often is a component of a larger product, which certainly was the case for the company that formed the basis for this case study. Thus, fully understanding site-level productivity differences requires analyzing the company's decisions to locate work remotely, not just in France but in other sites doing development work for the same set of products on which the U.S. and French teams worked. This meant expanding the scope of the study to include sites in the Czech Republic and India.

Because of interdependencies in the components produced at the remote sites, measuring productivity at the site level proved to be quite difficult. Should productivity be measured on the basis of meeting project goals for timeliness, cost, and design specifications for a particular component? Should it be measured based on the ability of the project integration teams to get the component to work seamlessly with the software? Is it possible to have site-level productivity measures when the final product is produced from components that are combined across sites? A framework for addressing these issues was derived from the organizational behavioral literature on teams and distributed work. The analysis focused on the tradeoffs between closer access to customers and markets, wage cost savings from locating the work in lower labor cost locations, and increased coordination and integration costs from distributing software development globally. Because of the challenges involved, the research used measures of self-reported effectiveness measured with respect to group-level objectives, derived from a survey administered to the group members, and from interviews conducted with both managers and employees at the sites. The combination of survey and interview data provides a detailed case study of the issues involved in distributing software R\&D work across the United States, Western Europe, and less-developed countries.

\subsection{Previous Literature}

While economists are the intended audience for this chapter, the existing literature on which the research approach is based lies predominantly outside of economics. The reason for this is because economics has only fairly recently begun to model the internal working of organizations, with a 
primary focus on principal-agent and property rights issues that have implications for organization design, including the boundaries of the firm, the allocation of decision making, and the structuring of incentives within the firm. The decision issue in this case, however, deals primarily with aspects of job design and organization design that address what Lawrence and Lorsch (1967) call the challenges of differentiation and integration: which tasks in the $R \& D$ and production process should be differentiated as separate from each other and thus can be located in different parts of the organization both conceptually and potentially also physically, and which tasks need to be integrated (and thus are conceptually tightly linked) with potential implications for physical proximity as well.

While a detailed analysis of the economic and organizational behavioral literatures on organization design is well beyond the scope of this chapter, it is worth noting how economics does (and does not) address the issue of groups and teams within organizations. Economics typically focuses on issues of where decision making happens in organizations (e.g., centrally or decentralized). While groups are sometimes addressed, the groups that exist within economic models are collections of individuals whose actions aggregate to form a collective output with complete efficiency (Marschak and Radner 1972; Gibbons 2003). In particular, "all team theoretic models share one key feature: they ignore the interests of the team members - there is no shirking, free-riding, lying, lobbying or strategizing of any kind . . the organization is a machine; its parts can be designed (and their interactions controlled)" (Gibbons 2003, 761). Unfortunately, anyone who has worked in groups, including academic departments, knows that these team theoretic models fall far short of describing the range of behaviors that exist and that impede efficiency in the real world.

The organizational behavioral literature, in contrast, has an entire discipline devoted to the study of groups and the difficulties in getting group members to behave in the ways the organization intends. Indeed, there are separate strands that focus, for example, on mandatory participation groups (often called teams) versus voluntary participation groups (called, among other things, social networks and learning networks). In these literatures, a group typically consists of three or more individuals, though two-person groups have been studied. ${ }^{1}$

For an economist, the theoretical justification for studying groups is grounded in specialization. Groups are the answer to this question: what happens when profit maximization requires individuals to rely closely on

1. The most common example of two-person groups from the teams literature is airline pilots. If the focus is expanded to include interactions between two individuals who are not peers, then there are entirely separate literatures on relationships that exist both as defined by the formal hierarchy of the firm (supervisor-subordinate relationships) and relationships that emerge voluntarily as a response to the organizational structure and individual's desire for outcomes such as career advancement (mentor relationships). 
the output of others (interdependence) and it is not feasible to assign full accountability for the overall product in piecemeal fashion? The traditional assembly line is a good example of interdependence: the ability of any assembly line worker to complete his or her task is directly tied to the actions of the worker immediately before him or her on the assembly line. Yet the traditional assembly line is not designed to assign accountability for the overall product to each individual worker, at least not in a profit maximizing way. The problem is that defects in the overall product quality often are not detected until well after they have occurred in the production process. While an individual worker can be held accountable for performing a very narrow task, such as inserting a screw, the worker cannot be held accountable in a cost effective way if minor deviations in the quality of the work are revealed only after the complete product has been assembled.

Traditional economic models would posit the use of monitoring and monetary incentives to produce the desired outcome. Yet examples from the real world show that organizations often deal with the problem by focusing on outcomes that can be measured only at the group level, and that necessitate holding a collection of individuals jointly responsible for the group output. In the case of assembly lines, the team-based approach, which was pioneered by the Japanese auto manufacturers, has become a standard adopted in manufacturing around the world. In this approach, groups of workers are jointly responsible and held accountable for assembling parts (or all) of the car in a way that allows for internal quality control within the group that can be accurately verified by others outside the group.

Other examples include the design of new products, which requires input from individuals with various specialized skill sets (engineering, marketing, design, finance, etc.), yet that also can only be measured as successful or not when the final product is produced, and the piloting of large jet planes. In the new product case, if it fails in the marketplace, it may be due to the standalone contributions of individual team members falling short, or to the fact that the individuals did not properly work together (cross-functionally) in the design of the product. The former is a failure of contribution, which can be measured at the individual level; the latter is a failure of cooperation, which can be measured only at the group level and that might not be accurately assessed by someone external to the group. In the jet plane case, the firm does not need, neither is it optimal, to know how the pilot and copilot divide the flying tasks, so long as the plane reaches its destination safely. The problem from the firm's perspective is how to create the right set of incentives for the individuals in the group to work together to achieve the outcome. The answer, as the organizational behavioral literature has shown, often is to create a team (Hackman and Oldham 1980; Hackman 1987).

According to the organizational behavioral literature, a team is "a collection of individuals who are interdependent in their tasks, who share responsibility for outcomes, who see themselves and are seen by others as an intact 
social entity embedded in one or more larger social systems (for example, business unit or the corporation), and who manage their relationships across organizational boundaries" (Cohen and Bailey 1997, 241). For economists, the latter two parts of the definition require further explanation. An "intact social entity" is another way of saying that the members of the group have to interact with each other in often fluid ways in order to accomplish the shared objectives. Having to "manage their relationships across organizational boundaries" means that traditional hierarchical approaches to organizing, evaluating, and rewarding individuals may not help, and might even hinder, achieving the group's objectives; successful performance may require ignoring or redefining those approaches.

Because economists typically prefer causal models, the prospects of focusing on fluid social interactions and how relationships get managed raises the uncomfortable specter of endogeneity. As such, to the extent that economists have focused on team issues, it has been limited to looking for ways that nontraditional approaches to designing work can improve productivity, of which teams form a core element as in the auto assembly case described previously. These nontraditional approaches have been called both high performance work systems and innovative HR approaches, and typically are characterized by bundles of work practices that deviate from the norm found in the job design approach used in traditional assembly lines (e.g., Appelbaum and Batt 1994; Cappelli and Neumark 2001; Kochan et al. 1996; Ichniowski, Shaw and Prennushi 1997). While there is some debate regarding the size of effects and the impacts on profitability (Cappelli and Neumark 2001), the economic and organizational behavioral literatures typically find a positive correlation between the use of these bundles of work practices, including teams, and productivity. Beyond this, however, economics largely is silent with respect to the role that teams play in organizations.

One reason why economists have been persuaded regarding the importance of innovative human resource practices and teams is the empirical evidence that comes almost exclusively from manufacturing showing their impact on productivity. Yet the use of teams is pervasive throughout all segments of the economy, not just manufacturing (Cohen and Bailey 1997). In knowledge-based work, which is a growing portion of all jobs, teams are useful in many contexts, including R\&D and customer service and sales; and, in the extreme, teams can form the basic organizing principle for an entire organization (Mohrman, Cohen, Mohrman 1995). In these settings, however, with the exception of sales, the types of productivity measures that economists prefer are difficult to impossible to come by.

The organizational behavioral literature on teams, in contrast, has spent much time wrestling with the issue of measuring productivity in settings where physical output measures are lacking. The most common approach is to survey the team members and others in the firm (supervisors, coworkers, customers, etc.) who are knowledgeable about the team's objectives and 
performance, asking them to rate the team on an "effectiveness" scalemeaning ability to accomplish the team's objectives. While such measures are more subjective than physical output measures, they have the advantage of enabling the rater to take into consideration organizational and external (market-based) factors that might otherwise confound effective comparison of outcomes for teams operating under different circumstances. Thus, a team that is hindered by unforeseen circumstances beyond its control could be rated more leniently than one that had smooth sailing. Similarly, any rating of effectiveness at achieving targets that can be measured using time or other counts (e.g., number of innovations) is done in relative terms, given that the rater should have a sense about how other people and teams should perform under comparable conditions. This means that effectiveness ratings can be very useful for comparing the drivers of performance across teams that have dissimilar and/or multiple objectives.

In addition to the outcome measures, the organizational behavioral literature focuses heavily on identifying the team characteristics and intermediate factors that impact productivity (Gladstein 1984; Keller 1986; Campion, Medsker, and Higgs 1993; Straus and McGrath 1994; Campion, Papper, and Medsker 1996; Guzzo and Dickson 1996; Cohen and Bailey 1997; Janz, Colquitt, and Noe 1997), factors that are not familiar to economists but that should appeal to economists' desires to better understand the black box of group dynamics. These include, but are hardly limited to, the measures used in this chapter, which are described in detail following.

In addition to the general factors that impact team effectiveness, the organizational behavioral literature recently has addressed the extent to which teams that operate in traditional settings (i.e., colocated) are different from teams that are geographically dispersed (i.e., one or more member is in a different location). A main focus of this literature is understanding how such geographically dispersed teams divide the work across locations, how they use technology to facilitate communication, and how time and distance impact team effectiveness (Hiltz, Johnson and Turoff 1986; Valacich et al. 1994; Saphiere 1996; Graetz et al. 1998; Cappel and Windsor 2000; McDonough, Kahn, and Barczak 2001; Schmidt, Montoya-Weiss, and Massey 2001; Bell and Kozlowski 2002; Driskell, Radtke, and Salas 2003; Gibson and Cohen 2003; Martins, Gilson, and Maynard 2004).

\subsection{Research Questions and Methods}

The research issues addressed in this study are as follows: are there differences in performance between the company's software development sites located in the United States, Western Europe, and other countries? If so, what drives those differences? Why would a company choose to locate software development work in such locations? And what are the prospects for future software development work in these locations?

To answer these questions a multimethod research approach was used, 
including interviews, site visits, and a survey at a large multinational technology company. The company, which must remain anonymous, was chosen because two of its business units have software development engineers in the United States, France, and Norway. Interviews with senior leaders of the firm revealed, however, that in order to understand software development location decisions, additional sites in the Czech Republic and India had to be included because development engineers in those locations worked in close cooperation with the engineers in the United States and France. The distribution of work across sites within the two business units is as follows:

- California (three sites) - Business Units A and B

- Texas-Unit B

- France-Unit B

- Czech Republic-Unit A

- Norway-Unit A

- India-Unit B

The research approach taken for this study is atypical of standard empirical economics studies that use existing data to test well-defined research questions. Rather, given the complexity of the work design, interdependencies across sites, and lack of existing data, the approach used elements of both "grounded theory" (Glaser and Strauss 1967; Strauss 1987; Marshall and Rossman 1995) and case study methodology (Yin 2003), which qualitative researchers in general and organizational behavior researchers in particular employ in situations such as this (Lee 1999). Lee (1999) and Yin (2003) provide excellent reviews of and frameworks for applying the methodologies involved in such research; the interested reader is encouraged to start with those sources for in-depth details. For purposes of brevity, the discussion here will focus on the steps taken for this particular study, and how they relate to the guidelines provided by those literatures.

The first step in the research process consisted of a review of the organizational behavioral literature on teams to identify the domain of factors that have been associated with team performance (see previous citations; Mohrman, Cohen, and Mohrman 1995; and Gibson and Cohen 2003). The second step consisted of interviews with the senior leadership of the company to identify business units and sites that had operations in both the United States and Western Europe and that produced similar products. The interviews also focused on the nature of the work and interdependencies across sites, and the history behind the company's rationale for locating software development work in each site. The latter was used for conclusions about strategy, motivation for starting and maintaining work at the different sites, and prospects for continued work at the sites. The former was used to narrow the domain of questions to address in the site visits, along with the types of workers (jobs/roles) to be interviewed during the site visits. The interview protocols addressed the following areas, using a semi-structured, open-ended format: 
- The individual's background, role on the team, and job responsibilities

- The team's objectives and structure

- Communication, information sharing, and conflict resolution between team members at different sites and among members within a site

- The benefits and costs of distributed work

- Team leadership and processes such as goal setting, coordination, and decision making

- Trust among the team members

- Performance management, rewards, and other HR practices that impact team effectiveness

- Lessons learned on how to improve the effectiveness of distributed teams

Site visits were conducted in California, Texas, France, and the Czech Republic, and included interviews with both managers and development engineers. For the Norway and India sites, telephone interviews were conducted with the site managers. The interview results were used to define the issues to be addressed in the survey, which was subsequently sent anonymously to all development engineers and on-site managers at each site. A copy of the survey and summary statistics for each question is in appendix B.

Figure 7.1 shows the model that was used to specify the regressions. It draws heavily from the work of Mohrman, Cohen, and Mohrman (1995), Gibson and Cohen (2003), and other contributions from the organizational behavioral literature on teams. There are three main parts of the model: (a) the group-related variables that are hypothesized to impact effectiveness ("effectiveness drivers"), (b) measures of the degree of distributed work, and (c) individual attitudes and intention to leave. The latter are included to investigate the impact that having team members located apart from each other may have on employees' satisfaction and desire to remain with the organization, potentially key issues in a knowledge work environment where turnover could negatively impact productivity. The model can be summarized using the following equations, which were used to guide the statistical analysis:

(1) Team effectiveness $=f$ (effectiveness drivers, individual attitudes,

$$
\text { degree of distributed work) }
$$

(2) Intention to leave $=g$ (individual attitudes, degree of distributed

$$
\text { work) }
$$

These equations and the diagram in figure 7.1 have the implicit assumption that both team effectiveness and intention to leave the organization are caused by the other variables. There are long intellectual histories in both economics and organizational behavior that support that perspective. For example, trust is viewed by the organizational behavior literature as a 


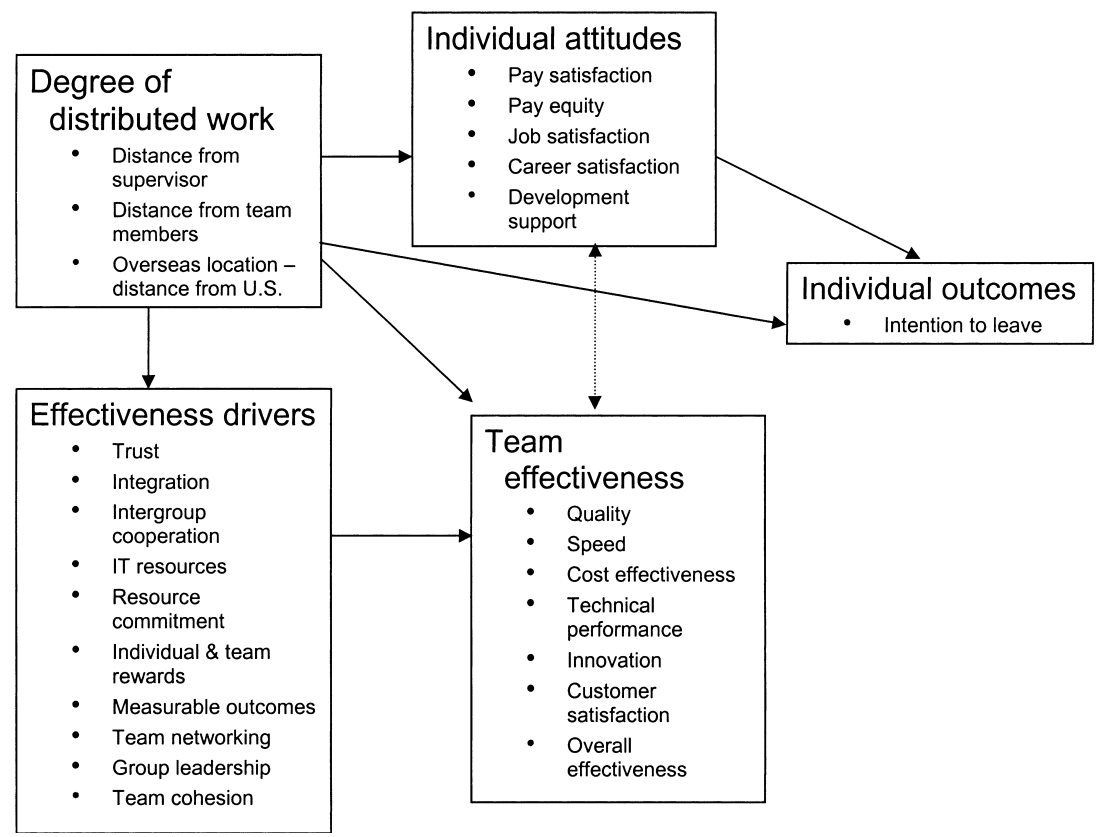

Fig. 7.1 Distributed team effectiveness model

key indicator that often precedes good group performance; in this view, trust among group members is a foundation upon which good performance is based (e.g., Mayer, Davis, and Schoorman 1995; Rousseau et al. 1998; Saparito, Chen, and Sapienza 2004; Mayer and Gavin 2005; Krishnan, Martin, and Noorderhaven 2006; Langfred 2007; Schoorman, Mayer, and Davis 2007). Within the economics literature, trust per se has been less of a focus than shirking in principal-agent, efficiency wage, and other models (e.g., Shapiro and Stiglitz 1984; Bulow and Summers 1986; Radner 1992; Prendergast 1999). In a group context, the absence of shirking could easily be conceptualized (and measured) as trust; viewed this way, many economic models support trust preceding performance.

In reality, however, it is reasonable to expect that there may be feedback loops from performance to employees' attitudes (the individual attitudes) and team processes, attitudes, and behaviors (the effectiveness drivers). For example, if team members are rewarded for their contributions only after the group's objectives have been achieved, their responses to the "individual and team rewards" construct questions could reflect the impact of prior performance on their most recently received compensation. ${ }^{2}$ Similarly, the levels

2. At a practical level, the very high alpha (.90) for that construct in this sample indicates that the individual survey items that comprise the construct are all highly correlated. Thus, in the context of teams in this firm, rewards for individual performance appear to be very closely tied into rewards for group performance, and vice versa. 
of trust, intergroup cooperation, resource commitment by the organization, and so forth, may all improve in the wake of prior good performance; ${ }^{3}$ indeed, this is the "virtuous spiral" that Lawler (2003) describes as common in high-performing organizations. The methodological issues involved in identifying causality in situations like this have been extensively addressed elsewhere (e.g., Cappelli and Neumark 2001). For the present purpose of demonstrating the types of measurement that can be used in team-based settings, the intent of the analysis is to test for a statistical relationship, not determine causality. In that context, the previous simplified equations are sufficient.

The data needed to estimate the model were collected using an online survey that was administered in 2004 to approximately 750 to 800 team members. The precise number of recipients is unknown because it was administered anonymously - the company distributed an e-mail request to all of the team members and on-site managers using an e-mail alias list that was not shared with the researchers. Valid responses were received from 204 people, for a response rate of approximately 25 to 30 percent. The company indicated that this response rate is consistent with their experience with other surveys. The respondents predominantly came from two of the three sites in California, France, the Czech Republic, and India. There were only a small number of respondents from the third site in California, Texas, and Norway, limiting the ability to draw direct inferences about these sites. At least one response was received from fifteen unique teams, with thirteen teams providing at least five responses per team.

The survey collected three measures of geographic dispersion: (a) location of the person, (b) distance of the respondents from their immediate supervisors (measured in number of time zones), and (c) whether the respondents regularly communicated with team members elsewhere (also measured in number of time zones). The latter were used to create dummy variables indicating the furthest distance from team members with whom the person interacted regularly. This person-specific measure of geographic dispersion was preferred to a team-level aggregate for two reasons. First, the interviews revealed that some of the teams included in the survey were predominantly colocated, with only a handful (sometimes only one or two) of members located elsewhere. Second, even within the highly geographically dispersed teams with, for example, no more than half their members at one location and the rest on different continents, many team members, according to the interviews, did not regularly communicate with other team members in far flung locations; this communication was typically reserved for the project lead or other team member playing a "lateral integrating role." Using a person-specific measure of geographic dispersion ensured that these

3. Or, as in the case of downsizing, poor business unit performance can reduce trust among the remaining employees (Mishra and Spreitzer 1998). 
differences in personal experience with distributed work were accurately reflected in the data and analysis.

The attitudinal measures that the survey sought to measure were drawn predominantly from previous research on teams and distributed teams in the organizational behavioral literature. The standard approach when collecting attitudinal measures is to ask multiple questions designed to address the same concept, and then use factor and reliability analysis to verify that the individuals' responses to the separate questions are sufficiently correlated that they can be combined together in indexes (using simple averages of the individual questions). The results of the factor and reliability analysis produced the following measures ("constructs") for the regression analyses. The individual survey items that form each construct are detailed in appendix A. The results of the Oblimin-rotated exploratory factor analysis using Principal Axis Factoring ${ }^{4}$ indicated that the items included in each construct factored with relatively high loadings within each construct and low cross-loadings across constructs (typically less than .3). The alphas from the reliability analyses ${ }^{5}$ are reported in appendix A.

1. Trust: Trust is supposed to be a key factor that measures whether team members can work together effectively in both colocated and distributed contexts.

2. Integration: Measures the extent to which team members who come from different disciplinary backgrounds can resolve their different perspectives.

3. Intergroup cooperation: The integration construct measures withinteam cooperation; this construct measures cooperation between functions and sites within the organization, which often go beyond the team members.

4. IT support: Measures the extent to which the team members perceive the organization provides sufficient technology support.

4. Broadly speaking, there are two types of "rotations" available to use when conducting exploratory factor analysis, both of which are designed to identify distinct groups of survey items that can be combined together based on common variance. Though there is a history of heated debate regarding the implicit assumptions underlying each approach, in practice both types of rotation yield similar results when dealing with relatively "clean" sets of survey items; that is, groups of survey items that have a high degree of within-group correlation (high within-group factor loadings) and a low degree of between-group correlation (low betweengroup factor loadings).

5. Calculating reliabilities (or "alphas") is a counterpart to exploratory factor analysis: any group of survey items that has high within-group correlation (factor loadings) usually has high reliability (alpha). The rule of thumb that has emerged over time with organizational behavioral research is to view constructs with alphas of .70 or higher as acceptable. It should be noted, however, that there is a direct analogy between this guideline and the guideline regarding "acceptable" $p$-values for hypothesis testing: though .05 has emerged over time as the dominant $p$-value cutoff used by most researchers, important information is conveyed by $p$-values in the .10 to .05 range, and in the .05 to .01 range. It is approximate, but reasonable, to say that the analogy to a $p$-value of .10 is an alpha of .60 , while the analogy to a $p$-value of .01 is an alpha of .80 (or even .90). 
5. Resource commitment: Similar to the previous construct, but focused broadly on any type of resource the team might need to be effective.

6. Individual and team rewards: Finding the right balance of individual versus group-based rewards is a key challenge when designing teams. This construct measures the extent to which the person perceives adequate alignment of rewards at both the individual and group level with both the individual's and the team's efforts and contributions.

7. Measurable outcomes: Having measurable outcomes should make it easier for team members to focus their efforts on actions that enhance effectiveness.

8. Team networking: Measures the extent to which the team works with other people in the company that can help it achieve its objectives.

9. Group leadership: Measures team member attitudes regarding leaders' roles in facilitating the team's work.

10. Team cohesion: Measures the extent of conflict among members of the team.

11. Intention to leave: A precursor to turnover, intention to leave has been shown to be a fairly reliable predictor in a number of settings.

12. Pay satisfaction: An attitudinal measure of whether the person is receiving wages at or above the reservation wage.

13. Job satisfaction: Though economists typically focus solely on the wage or total monetary compensation, models of job matching can be easily enhanced to include search for nonmonetary aspects in addition to monetary ones. This construct measures the overall quality of the match across all job aspects.

14. Career satisfaction: In addition to point-in-time issues related to a job match, the job may provide opportunities for career advancement through skill building that is needed for subsequent jobs.

15. Development support: On-the-job learning is a conscious activity that typically is acknowledged by economists only in the guise of formal training. However, the organizational behavioral literature has long recognized that there are active processes in which the employee can engage, including working with mentors and getting feedback on ways to improve skills on the job. This construct addresses those issues.

16. Work-life imbalance: Economic models of the labor market rarely address hours constraints, except in the constant of dual job holding (Paxson and Sicherman 1996). Such models focus on binding upper limits on hours worked that are created by overtime laws. Virtually ignored is the issue of binding lower limits on hours worked, something that has been noted in the nonacademic literature as a concern for professional workers (Schor 1991), and which has been addressed in the organizational behavioral literature as work-life imbalance.

For the effectiveness measures, the respondents were asked to rate their team along seven dimensions: (i) overall, (ii) quality, (iii) speed, (iv) cost, 
(v) technical performance, (vi) innovation, and (vii) customer satisfaction, using a 0 to 100 scale. These measures were initially identified as candidates based on a review of the teams literature, and were subsequently verified during the interviews with the senior executives of the company. To check the accuracy of the team members' perspectives, senior level managers (who did not take the survey) familiar with the team's objectives and processes were asked to rate the teams using the same effectiveness measures. These individual ratings were combined with those of the on-site managers to produce team-level aggregate (mean) manager ratings, which were compared to team-level aggregate employee ratings. The correlation between the manager and employee means across the seven outcome measures and fifteen teams was .41, which indicates a reasonable amount of agreement. While we would have preferred even greater consistency between manager and employee ratings of team effectiveness, given the small sample size we opted for combining the employee and on-site manager data when conducting the regression analyses. Because the on-site managers were active team members, including writing software computer code side-by-side with the nonmanagers, including their observations in the analysis seems warranted.

\subsection{Results}

Why did the company conduct software development work in these locations?

Interview results: The interviews with the firm's senior leaders indicated that seeking lower labor costs for software development work was one reason for moving such work overseas, though proximity to customers and acquisitions strategies played comparable if not larger roles. The company's headquarters is in the United States and much of its U.S.-based software development work is located in traditional centers of technology industry concentration, including the Bay Area in Northern California, Massachusetts, and Texas. When the company first set up operations in Western Europe, the initial offices had software sales and customer support responsibility only. In subsequent years, some of the end-stage development work was moved to Western Europe, including offices in France and Ireland. This included localization, which means adapting the software program to meet local language and other preferences. In keeping with the principles of distributed work, these end-stage processes are self-contained in the sense that they typically can be performed by stand-alone teams in the target countries with equal or better performance than if such work were performed closer to headquarters in the United States.

The success with moving end-stage software development work to Western Europe suggested to the firm's senior leadership that it might be feasible to move some of the earlier-stage development work as well. Aside from proximity to customers, the leadership perceived labor quality that was comparable to that available in the United States, with labor costs that 
were below those in the United States. ${ }^{6}$ The perceptions of labor quality came both from organic growth (hiring of additional software development engineers to work on existing products) and from acquisitions. In the case of Norway and the Czech Republic, part of the reason for the company's presence was due to acquiring companies based in those countries that had software products the U.S. company wanted to integrate into its own product offerings. In these cases, opening and maintaining "official" company operations offered the greatest chance of retaining the acquired firms' founders and employees, who were critical to the success of the integrated products. Thus, expansion in Western and Eastern Europe occurred both incrementally and in discrete jumps.

Incremental expansion only continued, however, as the company became adept at managing the work being done remotely. In each case, as a new site was established abroad, there was an initial learning curve regarding the best way to set up the technology and communications infrastructure, learn the local laws and labor regulations, and iron out the kinks of managing work that was being conducted many time zones away. Consistent with the literature on distributed teams (Gibson and Cohen 2003), the company learned the hard way the benefits of bringing team members together for face-to-face (FTF) meetings to establish trust, shared understanding, and integration among members working across large time, space, and culture differences. It also learned the need for ongoing FTF work by both team members and managers at regular intervals, which is accomplished by bringing people together at both the U.S. and abroad sites, depending on the stage of work and other considerations such as enabling the abroad team members to develop relationships with senior leaders in the United States, which both facilitates the team achieving its objectives and the individuals' ability to advance their careers within the firm.

With the perceived successful operation of software development sites in Western Europe, the company gained confidence that it could use its expertise in distributed software development to pursue even lower labor costs in India and China. In both of those cases, labor costs appear to have been more of a primary motivation than they were for the expansion into Western Europe. Interestingly, though, anecdotal evidence suggests that with the rapid expansion of outsourcing and software development work, particularly in India, labor costs have been rising much faster there in recent years than in the United States or Western Europe, eroding some, though hardly all, of the labor cost advantages. This apparently was the case with the site in Ireland, which started out with lower labor costs than the United

6. Historical data on labor cost differences was not available. However, the senior leaders' recollection is that the labor cost differences in the early years produced savings that were significant, though nowhere near as much as the current labor cost differences with Eastern Europe (approximately 50 percent of U.S. labor costs), India, and China (both approximately 33 percent of U.S. labor costs). 
States, but by the time of the study had labor costs within 90 percent of the United States.

Are there differences in performance between the company's software development sites located in the United States, Western Europe, and other countries?

Interview results: Labor cost differences are only one factor, albeit an important one, that impacts site performance. The other main benefit that emerged from the interviews was access to talent (skills) that are comparable or even better than the average talent available in the United States. Countering these advantages are the higher nonlabor costs from doing work over large distances. Because all software components produced abroad by this company eventually have to be integrated back into the components produced in the United States, the costs of coordinating and integrating the work produced at remote sites is greater than at sites in the United States.

A key factor in the higher integration costs is lack of overlap of the standard workday. For the Western European and California sites, there is only about one hour of overlap at the end of the day in Europe and the beginning of the day in California, during which all synchronous problem solving has to take place. This creates a significant burden on the team members who play the integrating roles, which can impact their job and career satisfaction, not to mention their productivity. The story that emerged from the interviews is that these employees do whatever it takes to get the work done (including sacrificing time with family and friends to work either late at night or early in the morning), but that they are subject to potentially greater burnout and turnover than the other employees.

Despite these difficulties, employees on both sides of the Atlantic who discussed their frustrations with the small overlap in the working day also said that they managed to work through the problems, finding a manageable equilibrium for the most part. Those on teams with members in California and India, in contrast, had no such equilibrium: the time difference is twelve hours, meaning that there is absolutely no overlap in the standard workday. The interviews suggested that these employees would be susceptible to the biggest imbalances between work and nonwork demands, with the highest potential for dissatisfaction and turnover.

Survey results: Descriptive statistics from the survey for each country are reported in table 7.1. The results of ANOVA tests for equality of each variable mean across the four countries are reported in the final column. The first seven rows report the outcome measures; the ANOVA results indicate that there is no statistically significant difference in the team effectiveness measures across the different sites. The point estimates in some cases differ by more than a small amount (e.g., the France site mean for speed is 70.6 percent effectiveness, compared to 80.5 for the Czech Republic site), but the standard deviations are equally large. This indicates a significant amount of within-site (and within-country, in the case of the United States, which 


\begin{tabular}{|c|c|c|c|c|c|}
\hline Mean (Standard deviation) & $\begin{array}{l}\text { United } \\
\text { States }\end{array}$ & France & $\begin{array}{c}\text { Czech } \\
\text { Republic }\end{array}$ & India & $\begin{array}{l}\text { ANOVA: test difference in } \\
\text { country means ( } p \text {-value) }\end{array}$ \\
\hline Overall effectiveness & $\begin{array}{c}73.9 \\
(20.3)\end{array}$ & $\begin{array}{c}79.5 \\
(10.9)\end{array}$ & $\begin{array}{c}75.2 \\
(17.6)\end{array}$ & $\begin{array}{l}78.3 \\
(8.4)\end{array}$ & .66 \\
\hline Quality & $\begin{array}{c}77.1 \\
(18.4)\end{array}$ & $\begin{array}{l}84.4 \\
(8.5)\end{array}$ & $\begin{array}{c}79.8 \\
(12.7)\end{array}$ & $\begin{array}{l}76.8 \\
(9.1)\end{array}$ & .56 \\
\hline Speed & $\begin{array}{l}73.9 \\
(22.5)\end{array}$ & $\begin{array}{c}70.6 \\
(12.4)\end{array}$ & $\begin{array}{r}80.5 \\
(16.4)\end{array}$ & $\begin{array}{l}77.6 \\
(11.8)\end{array}$ & .45 \\
\hline Cost effectiveness & $\begin{array}{c}77.9 \\
(20.3)\end{array}$ & $\begin{array}{c}81.5 \\
(14.9)\end{array}$ & $\begin{array}{c}75.9 \\
(29.9)\end{array}$ & $\begin{array}{l}87.6 \\
(9.5)\end{array}$ & .29 \\
\hline Technical performance & $\begin{array}{c}79.5 \\
(18.4)\end{array}$ & $\begin{array}{c}84.5 \\
(14.6)\end{array}$ & $\begin{array}{l}80.8 \\
(16.0)\end{array}$ & $\begin{array}{l}80.0 \\
(8.6)\end{array}$ & .84 \\
\hline Innovation & $\begin{array}{l}72.6 \\
(24.2)\end{array}$ & $\begin{array}{c}64.4 \\
(27.4)\end{array}$ & $\begin{array}{c}71.8 \\
(18.5)\end{array}$ & $\begin{array}{l}64.4 \\
(24.6)\end{array}$ & .48 \\
\hline Customer satisfaction & $\begin{array}{l}73.1 \\
(21.5)\end{array}$ & $\begin{array}{c}80.7 \\
(13.0)\end{array}$ & $\begin{array}{c}62.6 \\
(23.3)\end{array}$ & $\begin{array}{l}74.3 \\
(8.1)\end{array}$ & .14 \\
\hline Trust & $\begin{array}{l}4.1 \\
(0.84)\end{array}$ & $\begin{array}{l}4.3 \\
(0.57)\end{array}$ & $\begin{array}{l}4.1 \\
(0.56)\end{array}$ & $\begin{array}{l}4.0 \\
(0.62)\end{array}$ & .86 \\
\hline Integration & $\begin{array}{l}4.5 \\
(0.48)\end{array}$ & $\begin{array}{l}4.4 \\
(0.46)\end{array}$ & $\begin{array}{l}4.3 \\
(0.41)\end{array}$ & $\begin{array}{l}4.1 \\
(0.53)\end{array}$ & $.00^{* * *}$ \\
\hline Intergroup cooperation & $\begin{array}{l}3.7 \\
(0.93)\end{array}$ & $\begin{array}{l}3.8 \\
(0.67)\end{array}$ & $\begin{array}{l}3.5 \\
(0.59)\end{array}$ & $\begin{array}{l}3.9 \\
(0.61)\end{array}$ & .47 \\
\hline IT support & $\begin{array}{c}3.5 \\
(1.09)\end{array}$ & $\begin{array}{l}4.0 \\
(0.60)\end{array}$ & $\begin{array}{c}3.2 \\
(0.92)\end{array}$ & $\begin{array}{l}3.2 \\
(0.90)\end{array}$ & .20 \\
\hline Resource commitment & $\begin{array}{l}2.4 \\
(1.08)\end{array}$ & $\begin{array}{l}2.9 \\
(0.86)\end{array}$ & $\begin{array}{l}2.9 \\
(0.91)\end{array}$ & $\begin{array}{l}2.9 \\
(0.78)\end{array}$ & $.05^{*}$ \\
\hline Individual and team rewards & $\begin{array}{l}2.8 \\
(1.00)\end{array}$ & $\begin{array}{l}2.7 \\
(1.09)\end{array}$ & $\begin{array}{l}2.7 \\
(0.95)\end{array}$ & $\begin{array}{l}3.2 \\
(0.94)\end{array}$ & .40 \\
\hline Measurable outcomes & $\begin{array}{l}3.7 \\
(1.04)\end{array}$ & $\begin{array}{l}4.2 \\
(0.94)\end{array}$ & $\begin{array}{l}3.7 \\
(0.70)\end{array}$ & $\begin{array}{l}3.9 \\
(0.73)\end{array}$ & .35 \\
\hline Team networking & $\begin{array}{l}3.9 \\
(0.75)\end{array}$ & $\begin{array}{l}4.0 \\
(0.69)\end{array}$ & $\begin{array}{l}3.6 \\
(0.66)\end{array}$ & $\begin{array}{l}3.7 \\
(0.56)\end{array}$ & .24 \\
\hline Group leadership & $\begin{array}{l}3.8 \\
(1.06)\end{array}$ & $\begin{array}{l}4.5 \\
(0.96)\end{array}$ & $\begin{array}{l}4.0 \\
(0.69)\end{array}$ & $\begin{array}{l}3.8 \\
(0.96)\end{array}$ & .24 \\
\hline Team cohesion & $\begin{array}{l}3.3 \\
(0.70)\end{array}$ & $\begin{array}{l}3.7 \\
(0.62)\end{array}$ & $\begin{array}{l}3.7 \\
(0.50)\end{array}$ & $\begin{array}{l}3.5 \\
(0.38)\end{array}$ & $.02^{* *}$ \\
\hline Intention to leave & $\begin{array}{l}2.8 \\
(1.20)\end{array}$ & $\begin{array}{l}2.7 \\
(1.23)\end{array}$ & $\begin{array}{l}2.5 \\
(1.07)\end{array}$ & $\begin{array}{l}3.0 \\
(0.90)\end{array}$ & .66 \\
\hline Pay satisfaction & $\begin{array}{l}3.1 \\
(1.25)\end{array}$ & $\begin{array}{l}2.7 \\
(1.08)\end{array}$ & $\begin{array}{c}2.9 \\
(1.30)\end{array}$ & $\begin{array}{l}2.0 \\
(0.84)\end{array}$ & $.00 * * *$ \\
\hline Job satisfaction & $\begin{array}{c}3.7 \\
(1.03)\end{array}$ & $\begin{array}{l}4.1 \\
(0.66)\end{array}$ & $\begin{array}{l}3.9 \\
(0.77)\end{array}$ & $\begin{array}{c}3.4 \\
(0.80)\end{array}$ & .30 \\
\hline Career satisfaction & $\begin{array}{l}3.1 \\
(1.22)\end{array}$ & $\begin{array}{l}3.1 \\
(1.07)\end{array}$ & $\begin{array}{l}3.2 \\
(0.87)\end{array}$ & $\begin{array}{l}3.2 \\
(0.75)\end{array}$ & .97 \\
\hline Development support & $\begin{array}{l}2.5 \\
(1.07)\end{array}$ & $\begin{array}{l}2.5 \\
(1.26)\end{array}$ & $\begin{array}{c}2.6 \\
(1.01)\end{array}$ & $\begin{array}{l}2.9 \\
(1.04)\end{array}$ & .44 \\
\hline Work-life imbalance & $\begin{array}{l}3.3 \\
(1.17)\end{array}$ & $\begin{array}{l}3.2 \\
(0.88)\end{array}$ & $\begin{array}{l}3.3 \\
(0.81)\end{array}$ & $\begin{array}{l}3.4 \\
(0.96)\end{array}$ & .98 \\
\hline $\begin{array}{l}\text { Supervisor located in same time } \\
\text { zone, but different location }\end{array}$ & $\begin{array}{c}0.15 \\
(0.36)\end{array}$ & $\begin{array}{c}0 \\
(0)\end{array}$ & $\begin{array}{c}0 \\
(0)\end{array}$ & $\begin{array}{c}0 \\
(0)\end{array}$ & $.02^{* *}$ \\
\hline
\end{tabular}




\begin{tabular}{|c|c|c|c|c|c|}
\hline Mean (Standard deviation) & $\begin{array}{l}\text { United } \\
\text { States }\end{array}$ & France & $\begin{array}{l}\text { Czech } \\
\text { Republic }\end{array}$ & India & $\begin{array}{l}\text { ANOVA: test difference in } \\
\text { country means ( } p \text {-value) }\end{array}$ \\
\hline $\begin{array}{l}\text { Supervisor located } 1-3 \text { or } 4-7 \\
\text { time zones away }\end{array}$ & $\begin{array}{c}0.09 \\
(0.29)\end{array}$ & $\begin{array}{c}0.10 \\
(0.32)\end{array}$ & $\begin{array}{c}0 \\
(0)\end{array}$ & $\begin{array}{c}0 \\
(0)\end{array}$ & .19 \\
\hline $\begin{array}{l}\text { Supervisor located } 8-9 \text { or } 10- \\
12 \text { time zones away }\end{array}$ & $\begin{array}{c}0.01 \\
(0.12)\end{array}$ & $\begin{array}{c}0 \\
(0)\end{array}$ & $\begin{array}{c}0.31 \\
(0.47)\end{array}$ & $\begin{array}{c}0.41 \\
(0.50)\end{array}$ & $.00 * * *$ \\
\hline $\begin{array}{l}\text { Distance of communication } \\
\text { with team members: 4-7 time } \\
\text { zones away }\end{array}$ & $\begin{array}{c}0.04 \\
(0.20)\end{array}$ & $\begin{array}{c}0 \\
(0)\end{array}$ & $\begin{array}{c}0 \\
(0)\end{array}$ & $\begin{array}{c}0 \\
(0)\end{array}$ & .48 \\
\hline $\begin{array}{l}\text { Distance of communication } \\
\text { with team members: } 8 \text { or } \\
\text { more time zones away }\end{array}$ & $\begin{array}{c}0.70 \\
(0.46)\end{array}$ & $\begin{array}{c}0.80 \\
(0.42)\end{array}$ & $\begin{array}{c}0.77 \\
(0.43)\end{array}$ & $\begin{array}{c}0.82 \\
(0.39)\end{array}$ & .60 \\
\hline $\begin{array}{l}\text { Small change in product life } \\
\text { cycle }\end{array}$ & $\begin{array}{c}0.13 \\
(0.34)\end{array}$ & $\begin{array}{c}0.11 \\
(0.33)\end{array}$ & $\begin{array}{c}0 \\
(0)\end{array}$ & $\begin{array}{c}0.32 \\
(0.48)\end{array}$ & $.01 * *$ \\
\hline
\end{tabular}

Notes: Number observations: United States (144), France (10), Czech Republic (26), India (22). Observations from Norway (2) not included in calculations for this table.

***Significant at the 1 percent level.

**Significant at the 5 percent level.

*Significant at the 10 percent level.

has multiple sites) differences in effectiveness ratings. Separate anovas, not reported in the table, testing differences across the three main sites in the United States found a similar pattern of no statistically significant differences in any of the effectiveness ratings ( $p$-value $>.10$ in each case).

The results from analyzing the drivers of team effectiveness are presented in table 7.2. In each case the ten effectiveness drivers are regressed on the effectiveness measure in the first stage, and then the indicators for degree of collaboration across time zones, distance from supervisor, and location are entered in the second stage.

The results in table 7.2 indicate that the relationships between the effectiveness drivers and (perceived) outcome measures are consistent with the existing literature on teams. In particular, trust, intergroup cooperation, IT support, resource commitment, team networking, and team cohesion all are statistically significantly positively related to at least one of the effectiveness measures. All of the coefficients are either statistically significantly positive or not significantly different from zero; none are negative and statistically significant.

The indicators for geographic dispersion and location do not provide much support for the notion that having the software development work located in far-flung locations negatively impacts team effectiveness. Having to regularly communicate with team members either four to seven or eight or more time zones away does not appear to impact effectiveness, relative to those who do not regularly communicate with team members 


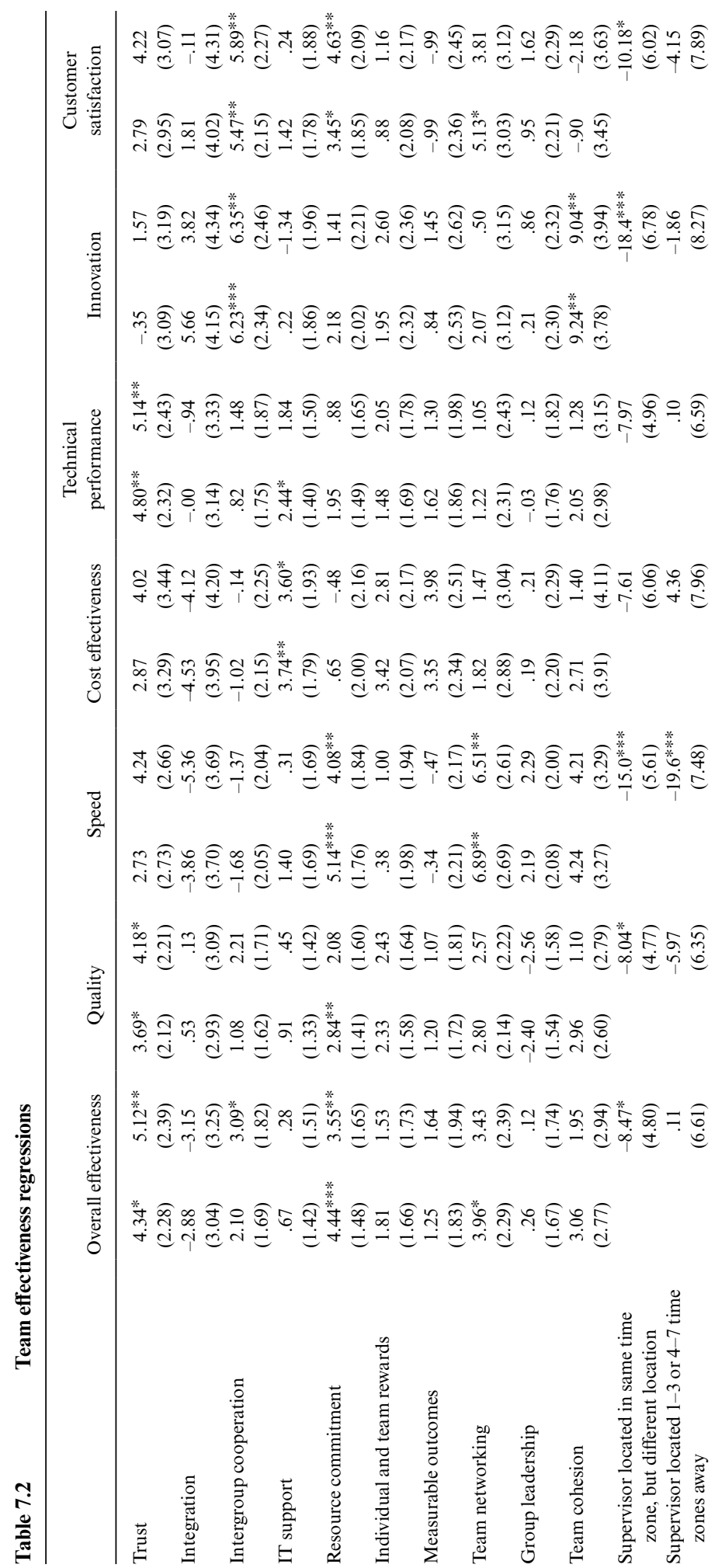




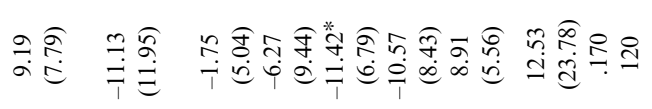

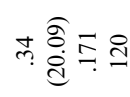

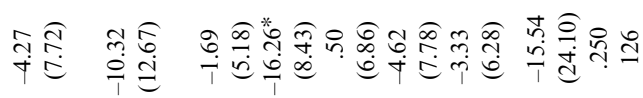

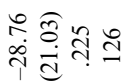

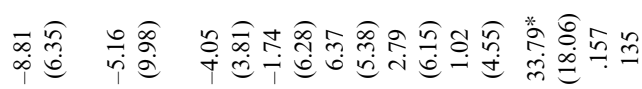
공ำ

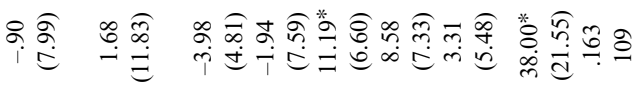

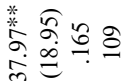

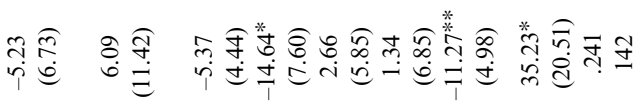
究递主专

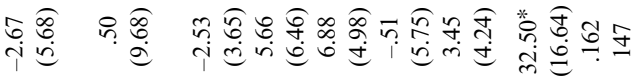
ते

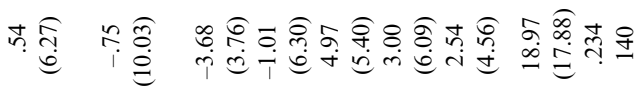

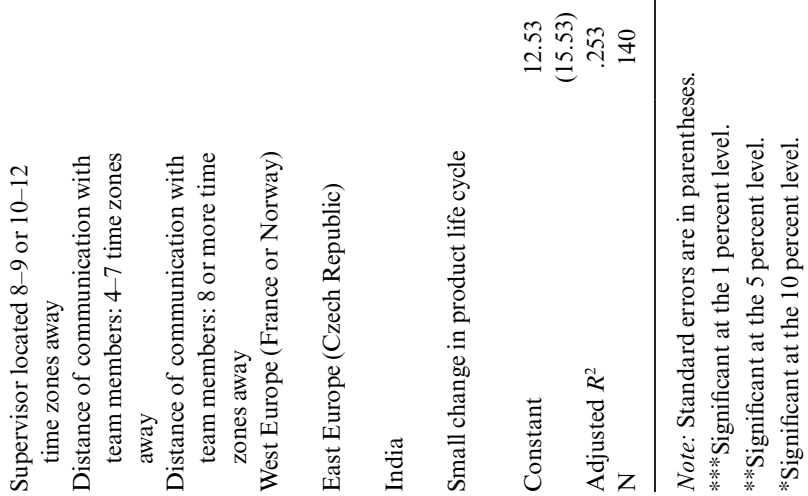


so far away. Similarly, having a supervisor eight or more time zones away also does not differentiate effectiveness, relative to those who are colocated with their supervisors. Interestingly, those whose immediate supervisor is at a different location but in the same time zone (typically those at the California sites) report lower overall effectiveness, quality, speed, innovation, and customer satisfaction. As the results in table 7.3 show, this most likely is because these same people report worse IT support and resource commitment (in the regression context that controls for the other included variables), whereas team members in both the Czech Republic and in India report higher resource commitment than the software engineers located at the company's headquarters. ${ }^{7}$ With the company focusing so heavily on trying to make things work for team members located on different continents, the results in tables 7.1 and 7.2 suggest that they may be missing an opportunity to improve performance by mending the fences that are much closer to home (i.e., those who are in the same time zone but not located at headquarters).

Very few of the location indicators are significant in table 7.2. Team members in France ${ }^{8}$ report lower speed and innovation, which is consistent with the interviews. Some of the U.S.-based leadership expressed high degrees of satisfaction with the French sites' quality, but low satisfaction with their responsiveness. The Czech Republic site, in contrast, was viewed as having software engineers who were less complacent, more "hungry" to succeed regardless of the personal sacrifices that might be needed. Perhaps in part because of this, the respondents at the Czech Republic site reported higher cost effectiveness. They also, however, reported lower customer satisfaction; their drive to succeed within the cost parameters thus may produce unintended costs downstream with lower sales. This story is consistent with one senior leadership interviewee who expressed frustration at what appeared to be an ongoing need to have senior technical experts in the United States intervene in the Czech Republic team's work to fix problems that occurred with higher frequency than other sites such as France.

At this point it is worth noting the impact of both IT and HR practices in impacting effectiveness for these teams. For IT support, at first glance it may seem surprising that variation in this is related to effectiveness only on the cost and technical performance fronts. Yet this company, like most, strives for consistency in practices across sites within the same business unit; if a certain level of technology support is provided in the United States because

7. Note, however, that this effect only exists for those who are located in India and the Czech Republic who do not have to communicate on a regular basis with team members in the United States - the coefficients on communicating with team members both four to seven and eight or more time zones away are negative and significant.

8. The indicator in the tables is for team members in either France or Norway; however, the vast majority of these are in France so those respondents undoubtedly dominate the estimated relationships. 


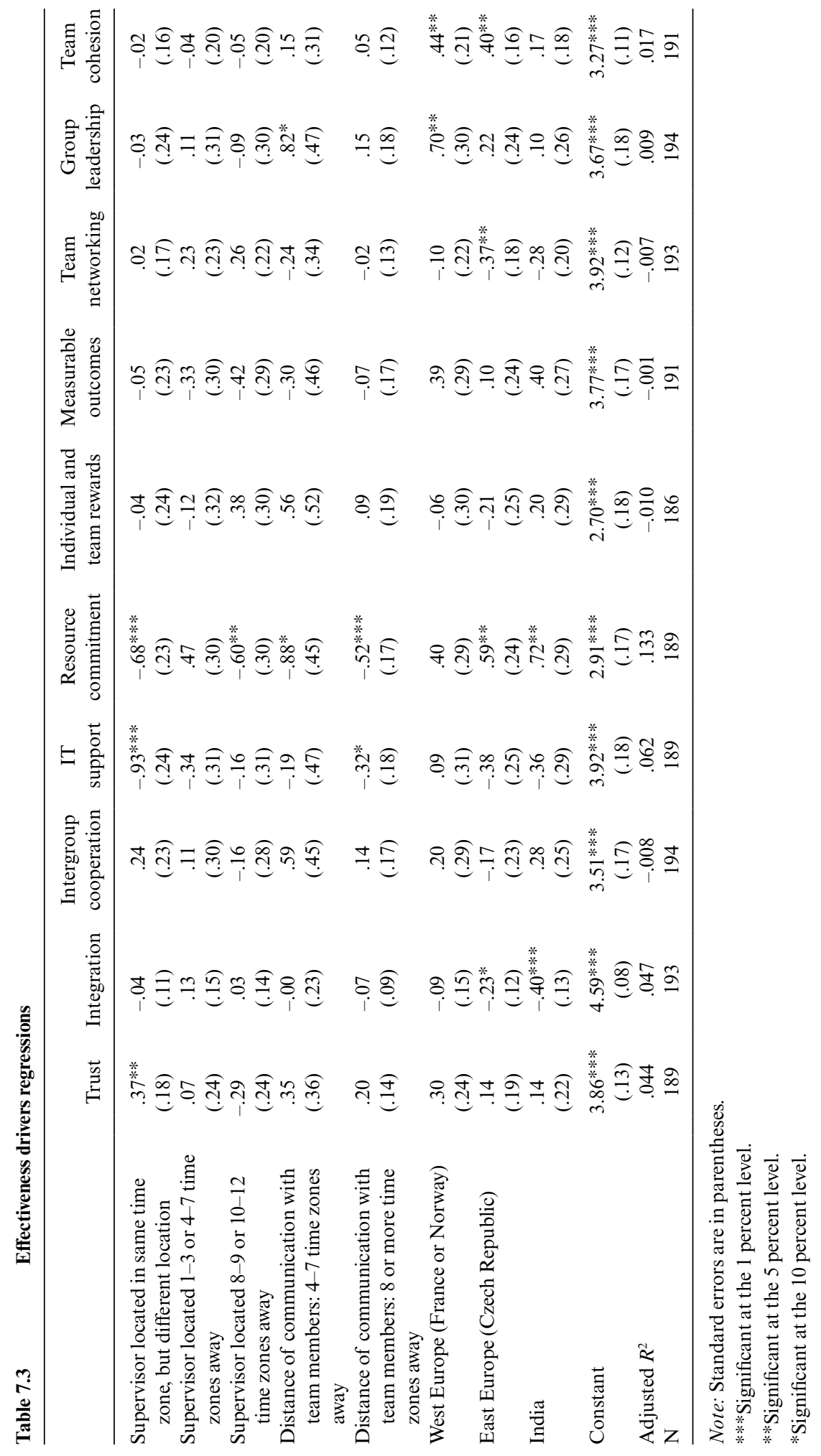


that is what it takes to get the job done, the expectation of the company's leaders is that the same level of support will be provided at all sites. Thus, within-company analyses such as these often suffer from a range restriction problem: most employees should experience much lower variation in practices within a company than if we were to compare employees across companies.

For HR practices the range restriction issue may be less stark, but still important. Range restriction is an issue because the desire to promote common ways of communicating and rewarding performance lead to consistency of HR practices across sites. The need to do some adaptation to local preferences, however, has the potential to introduce more variation in HR practices than might be expected for IT support. For the French site, in particular, the national restrictions on firing have significantly impacted how the company uses the site. Initially there was no expectation that a downturn in business would lead to headcount adjustment problems in France. Yet this is precisely what happened a few years prior to the study, when the company tried to remove costs at many of its sites around the globe in response to a business downturn. The difficulties in laying off software engineers in France led the company to manage the site differently, focusing on keeping headcount the same or even falling through natural attrition. Yet despite this emphasis, the French site continues to be given highly technical components of the work in no small part because of the stability of the employees and their high level of expertise. Thus, both IT and HR practices appear to matter, but in ways that do not necessarily impact measured productivity at a single point in time, as these data do.

Moving to the attitudinal data, table 7.4 reports the correlation of overall team effectiveness with the intention to leave, satisfaction, perceived development support, and work-life imbalance variables. As expected, and consistent with previous research, there is a reasonably large positive correlation with satisfaction and development support, and negative correlation with intention to leave. As Lawler (2003) has argued, these results are consistent with mutually reinforcing HR practices and employee actions: a supportive environment creates the conditions for effective performance, which makes it easier for the firm to spend money and take the time to do things to keep its employees happy, which improves retention, which helps performance, and so forth. This perspective is further supported by the results in table 7.5, which show a strong negative correlation between intentions to leave the firm and satisfaction, development support, and work-life balance (column [1]), regardless of how geographically dispersed the team members are (column [2]).

Finally, the results in table 7.6 indicate that geographic dispersion of team members is not related to satisfaction, development support, or work-life imbalance. The one difference that stands out is for team members located 
Correlations of overall team effectiveness and individual attitudes

\begin{tabular}{lcccccc}
\hline Pearson $(\mathrm{N})$ & $\begin{array}{c}\text { Overall team } \\
\text { effectiveness }\end{array}$ & $\begin{array}{c}\text { Intention } \\
\text { to leave }\end{array}$ & $\begin{array}{c}\text { Pay } \\
\text { satisfaction }\end{array}$ & $\begin{array}{c}\text { Job } \\
\text { satisfaction }\end{array}$ & $\begin{array}{c}\text { Career } \\
\text { satisfaction }\end{array}$ & $\begin{array}{c}\text { Development } \\
\text { support }\end{array}$ \\
\hline $\begin{array}{l}\text { Intention to } \\
\text { leave }\end{array}$ & $\begin{array}{c}-.22^{* * *} \\
(160)\end{array}$ & & & & & \\
Pay & .09 & $-.33^{* * *}$ & & & & \\
$\quad$ satisfaction & $(160)$ & $(190)$ & & & & \\
Job & $.37^{* * *}$ & $-.67^{* * *}$ & $.33^{* * *}$ & & & \\
$\quad$ satisfaction & $(161)$ & $(192)$ & $(190)$ & & & \\
Career & $.22^{* * *}$ & $-.48^{* * *}$ & $.37^{* * *}$ & $.49^{* * *}$ & & \\
$\quad$ satisfaction & $(161)$ & $(190)$ & $(191)$ & $(191)$ & & \\
Development & $.31^{* * *}$ & $-.45^{* * *}$ & $.32^{* * *}$ & $.44^{* * *}$ & $.49^{* * * *}$ & \\
$\quad$ support & $(160)$ & $(191)$ & $(189)$ & $(192)$ & $(190)$ & \\
Work-life & .09 & $.19^{* * *}$ & -.11 & -.03 & -.05 & -.05 \\
$\quad$ imbalance & $(160)$ & $(191)$ & $(189)$ & $(192)$ & $(190)$ & $(191)$ \\
\hline
\end{tabular}

***Significant at the 1 percent level.

**Significant at the 5 percent level.

*Significant at the 10 percent level.

in India, who reported lower pay satisfaction and job satisfaction. This is consistent with anecdotes that wages are rising relatively fast in India. The results indicate that the firm's HR policies regarding pay may not be responding quickly enough to changes in the external environment.

What are the prospects for future software development work in these locations? The survey results indicated that, on average, there are not many differences in reported effectiveness for work that is done at the different sites. This, in large part, likely is due to the interdependent nature of work that takes place not just at those sites, but in the United States as well. Given the company's strong preference for making overall product decisions and doing the final integration work in the United States, it is hard to foresee a scenario in which such integration costs could be lowered without a major shift in the way overall product development decisions are made. Thus, to the extent that the company continues to do this kind of software development work in general, the data and interviews suggest that there is no reason to expect a pullback from working in these regions.

That said, the desire to seek lower labor costs suggests that future growth in software engineering headcount is liable to take place in the Czech Republic, India, and China. On the one hand, at the time of the study the Czech Republic's labor costs were about one half those in the United States, whereas the labor costs in India and China were lower, at about one third those in the United States. Countering the lower labor costs of India and China, however, the Czech Republic is closer to the United States, which makes synchronous communication much easier to do, even if it is concentrated at 
Table 7.5 Intention to leave regressions

\begin{tabular}{|c|c|c|}
\hline Pay satisfaction & $\begin{array}{l}-.05 \\
(.05)\end{array}$ & $\begin{array}{l}-.03 \\
(.06)\end{array}$ \\
\hline Job satisfaction & $\begin{array}{l}-.61 * * * \\
(.07)\end{array}$ & $\begin{array}{l}-.62^{* * *} \\
(.08)\end{array}$ \\
\hline Career satisfaction & $\begin{array}{l}-.16^{* *} \\
(.07)\end{array}$ & $\begin{aligned}-.13^{*} \\
(.07)\end{aligned}$ \\
\hline Development support & $\begin{array}{l}-.17 * * \\
(.07)\end{array}$ & $\begin{array}{l}-.19^{* * *} \\
(.07)\end{array}$ \\
\hline Work-life imbalance & $\begin{array}{l}.16^{* * * *} \\
(.05)\end{array}$ & $\begin{array}{l}.13^{* *} \\
(.06)\end{array}$ \\
\hline $\begin{array}{l}\text { Supervisor located in same time zone, but different } \\
\text { location }\end{array}$ & & $\begin{array}{l}-.32 \\
(.20)\end{array}$ \\
\hline Supervisor located $1-3$ or $4-7$ time zones away & & $\begin{array}{l}.12 \\
(.26)\end{array}$ \\
\hline Supervisor located $8-9$ or $10-12$ time zones away & & $\begin{array}{l}-.13 \\
(.25)\end{array}$ \\
\hline $\begin{array}{l}\text { Distance of communication with team members: } 4-7 \\
\text { time zones away }\end{array}$ & & $\begin{array}{l}-1.06^{* * *} \\
(.37)\end{array}$ \\
\hline $\begin{array}{l}\text { Distance of communication with team members: } 8 \text { or } \\
\text { more time zones away }\end{array}$ & & $\begin{array}{l}.09 \\
(.16)\end{array}$ \\
\hline West Europe (France or Norway) & & $\begin{array}{l}-.09 \\
(.26)\end{array}$ \\
\hline East Europe (Czech Republic) & & $\begin{array}{l}-.06 \\
(.21)\end{array}$ \\
\hline India & & $\begin{array}{l}-.02 \\
(.27)\end{array}$ \\
\hline Organization tenure & & $\begin{array}{l}-.09 \\
(.08)\end{array}$ \\
\hline Years of experience working on distributed teams & & $\begin{array}{l}.02 \\
(.02)\end{array}$ \\
\hline Constant & $\begin{array}{l}5.54 * * * \\
(.32)\end{array}$ & $\begin{array}{l}5.76^{* * * *} \\
(.42)\end{array}$ \\
\hline Adjusted $R^{2}$ & .526 & .540 \\
\hline$N$ & 179 & 179 \\
\hline
\end{tabular}

Note: Standard errors are in parentheses.

***Significant at the 1 percent level.

**Significant at the 5 percent level.

*Significant at the 10 percent level.

the end of the day in Europe and beginning of the day in the United States. This suggests that the type of work that is done in the Czech Republic may have greater complexity than the work that is done in India or Chinaunless the company moves toward allowing complete pieces of software to be developed in those sites that are the furthest removed from headquarters. In France, the prospects appear to be continued work, but no expansion in the number of software engineers, and thus a low or diminished profile with respect to the company's overall software development efforts. 
Individual attitudes regressions

\begin{tabular}{lccccc}
\hline & $\begin{array}{c}\text { Pay } \\
\text { satisfaction }\end{array}$ & $\begin{array}{c}\text { Job } \\
\text { satisfaction }\end{array}$ & $\begin{array}{c}\text { Career } \\
\text { satisfaction }\end{array}$ & $\begin{array}{c}\text { Development } \\
\text { support }\end{array}$ & $\begin{array}{c}\text { Work-life } \\
\text { imbalance }\end{array}$ \\
\hline Supervisor located in same time & $.56^{* *}$ & -.27 & .36 & .05 & -.07 \\
$\quad$ zone, but different location & $(.28)$ & $(.22)$ & $(.27)$ & $(.25)$ & $. .26)$ \\
Supervisor located 1-3 or 4-7 & .46 & $.60^{* *}$ & .02 & -.53 & -.19 \\
$\quad$ time zones away & $(.37)$ & $(.29)$ & $(.35)$ & $(.33)$ & $(.34)$ \\
Supervisor located 8-9 or 10- & .28 & .33 & .29 & .37 & .52 \\
$\quad$ 12 time zones away & $(.34)$ & $(.27)$ & $(.33)$ & $(.31)$ & $(.32)$ \\
Distance of communication & & & & & \\
$\quad$ with team members: 4-7 time & -.25 & .27 & .47 & -.11 & -.34 \\
zones away & $(.57)$ & $(.44)$ & $(.53)$ & $(.50)$ & $(.52)$ \\
Distance of communication & & & & & \\
$\quad$ with team members: 8 or & -.30 & .19 & -.11 & -.30 & .01 \\
more time zones away & $(.21)$ & $(.17)$ & $(.20)$ & $(.19)$ & $(.19)$ \\
West Europe (France or & -.40 & .30 & .11 & .12 & .06 \\
$\quad$ Norway) & $(.37)$ & $(.29)$ & $(.34)$ & $(.32)$ & $(.33)$ \\
East Europe (Czech Republic) & -.19 & .04 & .09 & -.01 & -.19 \\
& $(.29)$ & $(.23)$ & $(.27)$ & $(.25)$ & $(.26)$ \\
India & $-1.06^{* * *}$ & $-.43^{*}$ & .07 & .28 & -.15 \\
& $(.31)$ & $(.26)$ & $(.30)$ & $(.30)$ & $(.30)$ \\
Constant & $3.20^{* * *}$ & $3.58^{* * *}$ & $3.10^{* * * *}$ & $2.71^{* * *}$ & $3.31^{* * *}$ \\
Adjusted $R^{2}$ & $(.21)$ & $(.16)$ & $(.19)$ & $(.18)$ & $(.18)$ \\
$N$ & .082 & .036 & -.020 & .005 & -.019 \\
& 193 & 193 & 193 & 192 & 192 \\
\hline
\end{tabular}

Note: Standard errors are in parentheses.

*** Significant at the 1 percent level.

**Significant at the 5 percent level.

*Significant at the 10 percent level.

\subsection{Conclusions}

This study has found evidence in favor of the following conclusions:

1. International differences in productivity do not appear to be a big factor in explaining cross-sectional patterns of software development work location.

2. To the extent that geographic dispersion matters, spreading work out to the point where there is no overlap in the standard workday may put limits on the productivity of individual team members. However, the teams as a whole appear capable of dealing with such pressures without significantly impacting the teams' overall effectiveness.

3. Even though the data did not reveal average productivity differences across sites, this says nothing about marginal productivity differences. Given a set of strengths and weaknesses associated with conducting software development work in various sites, one would expect the firm to distribute the work in such a way that average productivity (and contributions to profit- 
ability) are equalized. Without a natural experiment that varies the type of work in a controlled way, it may be very difficult to detect marginal productivity differences.

\section{Appendix A}

\section{Glossary, Scales, and Reliabilities}

Trust, Integration, and Cooperation

Trust (alpha $=.90)$

E2. We can count on the people in our team to perform their jobs proficiently.

E10. Team members trust each other to contribute worthwhile ideas.

E12. We can trust that the members of our team have the knowledge and skills to complete their work.

E3. Team members always do what they say they will do.

E5. The people on our team are reliable in their work.

E7. Team members believe that others on our team will follow through on their commitments.

Integration (alpha $=.58)$

I2. I try to investigate an issue with others to find a solution acceptable to all.

I3. I try to integrate my ideas with those of others to come up with a decision jointly.

Intergroup Cooperation (alpha $=.70)$

D12. There is good cooperation between functions.

D15. There is good cooperation between sites.

IT Support and Resources

IT Support (alpha $=71)$

G3. We receive prompt technical assistance when our computer systems are not working.

G9. Company provides adequate information technology support.

Resource Commitment (alpha $=.75$ )

G1. Company has committed the resources required to do this work.

G5r. *We can't count on continuity of the resources we need. (reversed)

G8r. *We have to fight to hold on to the resources we need. (reversed)

Rewards and Goal Setting

Individual and Team Rewards (alpha $=.90)$

F2. How much pay I receive depends almost entirely on how well I perform my job.

F4. My contributions to this team are rewarded by the company.

F7. My pay level is determined by my individual job performance.

F13. My pay depends on the success of the teams I work with.

F17. Members of this team are rewarded commensurate with their contributions.

F18. Teams are rewarded in line with their performance here.

Measurable Outcomes (alpha $=.74$ )

F8. Our team's work has measurable team outcomes.

F16. Our team has quantifiable targets. 
Networking, Conflict, and Leadership

Team Networking (alpha $=.59)$

F3. My team forms alliances with people in different units at the company to work toward mutual objectives.

F6. My team maintains contacts with people in other parts of the company who can be a useful source of information, resources, and support.

Group Leadership (alpha $=.77$ )

D6. My immediate supervisor attempts to resolve disagreements in a constructive manner.

D7r. *Our leader is hesitant about taking initiative in the group. (reversed)

D11r. *Our leader fails to take necessary action. (reversed)

Team Cohesion (alpha $=.82)$

D1r. *How often do people in your team disagree about opinions regarding the work being done? (reversed)

D2r. *How much are personality conflicts evident in your team? (reversed)

D3r. *How frequently are there conflicts about ideas in your team? (reversed)

D4r. *How much tension is there among members in your team? (reversed)

D9. My team attempts to resolve disagreements in a constructive manner.

Satisfaction, Equity, and Support

Intention to Leave (alpha $=.82$ )

J7. I plan to look outside the company for a new job within the next year.

J16. It is likely that I will quit my job in the next twelve months.

Pay Satisfaction (alpha $=.94)$

J2. I am satisfied with my total compensation.

J12. I am satisfied with my current salary.

Pay Equity (alpha $=.74)$

J1. I believe I am fairly paid compared to my peers at company who are at equivalent job levels and who are equivalently skilled.

J9. I believe I am fairly paid compared to my peers in other companies who are at equivalent job levels and who are equivalently skilled.

Job Satisfaction (alpha $=.84)$

J4. All in all, I am satisfied with my job.

J19. In general, I like working here.

Career Satisfaction (alpha $=.84$ )

J6. I am satisfied with the progress I have made toward meeting my overall career goals.

J13. I am satisfied with the progress I have made toward meeting my goals for advancement.

Development Support (alpha $=.81)$

J15. The company has a good process for mentoring employees.

J20. The company has a good process for identifying employees' development needs.

Work-Life Imbalance (alpha $=.85$ )

J3. My work takes up time that I would like to spend with family/friends.

J18. My family/friends dislike how often I am preoccupied with my work while at home.

J21. On the job I have so much work to do that it takes away from my personal interests. 


\section{Appendix B}

\section{Survey Items and Summary Statistics}

A. Details of the Work

1. Please select your team: (NOTE: If you are on multiple teams, please answer this survey regarding the team on which you spend most of your time.) (required)

2. At what location do you primarily work? (required)

\begin{tabular}{|c|c|c|c|}
\hline $3.9 \%$ & Texas & $17.2 \%$ & California site \#2 \\
\hline $10.8 \%$ & India & $1.0 \%$ & Norway \\
\hline $4.9 \%$ & France & $2.5 \%$ & California site \#3 \\
\hline $37.7 \%$ & California site \#1 & $9.3 \%$ & Other (please specify): \\
\hline
\end{tabular}

$12.7 \%$ Czech Republic

3. What is your main function on this team? (required)

\begin{tabular}{|c|c|c|c|}
\hline $42.6 \%$ & Development Engineer & $1.5 \%$ & Technology Specialist \\
\hline $3.4 \%$ & Release Engineer & $4.4 \%$ & Architect \\
\hline $2.5 \%$ & Human Interface Engineer & $10.3 \%$ & Engineering Manager \\
\hline $6.4 \%$ & Sustaining Engineer & $2.5 \%$ & QA Manager \\
\hline $12.3 \%$ & Quality Engineer & $0 \%$ & Documentation Manager \\
\hline $0 \%$ & Localization Engineer / Testing & $1.5 \%$ & Product Manager \\
\hline $1.0 \%$ & Marketing & $7.8 \%$ & Other (please specify): \\
\hline
\end{tabular}

4. How long has this team been in existence? (round off to nearest number of months) 3.73 years

5. How long have you been on this team? (round off to nearest number of months) 2.65 years

6. At what stage in the product life cycle is your team's work? (choose one response only) $24.1 \%$ First release / entirely new product

$7.0 \%$ Updating an existing product with minor changes

$62.8 \%$ Updating an existing product with major changes

$6.0 \%$ Sustaining an existing product with little to no changes

$0 \%$ End of product life cycle / Ending an existing product

7. Where is your immediate supervisor located? (choose one response only)

$72.8 \%$ Colocated with me (same site)

$10.9 \%$ Different location, same time zone

$5.4 \%$ Different location, one to three time zones away

$1.5 \%$ Different location, four to seven time zones away

$5.0 \%$ Different location, eight to nine time zones away

$4.5 \%$ Different location, ten to twelve time zones away

8. Approximately what percentage of the members of your team are colocated? $\quad 61.2 \%$

9. Do you communicate regularly with members of your team at other sites? $\quad 83.8 \%$ Yes $16.2 \%$ No

If yes, where are the other members located? (choose all that apply)

$\underline{34.3 \%}$ Different location, same time zone

$\underline{30.4 \%}$ Different location, one to three time zones away

$15.2 \%$ Different location, four to seven time zones away 
$34.8 \%$ Different location, eight to nine time zones away

$42.6 \%$ Different location, ten to twelve time zones away

10. Are you actively involved in ensuring that communication occurs between your team and other members of the company? $\quad 67.3 \%$ Yes $32.7 \%$ No

If yes, where are the other members located? (choose all that apply)

$\underline{37.3 \%}$ Colocated with me (same site)

$25.0 \%$ Different location, same time zone

$\underline{25.5 \%}$ Different location, one to three time zones away

$13.2 \%$ Different location, four to seven time zones away

$\underline{30.4 \%}$ Different location, eight to nine time zones away

$31.9 \%$ Different location, ten to twelve time zones away

\section{B. Outcomes}

Compared to what is possible (100 percent), estimate how effective your team has been at each of the following using a percentage. For example, if Team X meets 80 percent of its quality goals compared to what is possible, enter 80 percent in the first item. If they do not apply, leave blank.

1. Quality

2. Speed (cycle time, time to market, etc.)

3. Cost effectiveness

4. Technical performance

5. Innovation

6. Customer satisfaction

7. Overall effectiveness

\section{Percent Effectiveness}

\begin{tabular}{l}
$77.9 \%$ \\
\hline $75.0 \%$ \\
\hline $80.1 \%$ \\
\hline $71.3 \%$ \\
\hline $72.3 \%$ \\
\hline $75.0 \%$ \\
\hline
\end{tabular}

\section{Degree of Distributed Work}

For items 1-6, rate using two columns: How important are each of the following technologies to getting your work done in this team? In the second column, indicate the percentage of your time spent on each technology (the total across all six technologies should equal 100 percent).

\begin{tabular}{|c|c|c|c|c|c|c|}
\hline $\begin{array}{c}\text { Not } \\
\text { Important }\end{array}$ & $\begin{array}{l}\text { Somewhat } \\
\text { Important }\end{array}$ & Important & $\begin{array}{c}\text { Very } \\
\text { Important }\end{array}$ & $\begin{array}{l}\text { Extremely } \\
\text { Important }\end{array}$ & Mean & $\begin{array}{l}\% \text { of Time } \\
\text { Spent on } \\
\text { Each } \\
\text { Technology }\end{array}$ \\
\hline 0 & 0 & 3.5 & 19.7 & 76.8 & 4.73 & $48.5 \%$ \\
\hline 5.2 & 11.9 & 34.5 & 34.5 & 13.9 & 3.40 & $12.9 \%$ \\
\hline 4.3 & 14.4 & 24.1 & 41.7 & 15.5 & 3.50 & $14.4 \%$ \\
\hline 22.8 & 37.0 & 18.5 & 15.8 & 6.0 & 2.45 & $6.8 \%$ \\
\hline 58.3 & 19.8 & 14.4 & 6.4 & 1.1 & 1.72 & $2.6 \%$ \\
\hline 3.1 & 17.8 & 31.4 & 24.1 & 23.6 & 3.47 & $20.6 \%$ \\
\hline
\end{tabular}


7. To what extent are you reliant on electronic communication to accomplish your collaboration in your team?

$\frac{0}{\text { Not At All }} \quad \frac{0.5}{\text { Some Extent }} \quad \frac{\begin{array}{c}\text { Moderate } \\ \text { Extent }\end{array}}{\begin{array}{c}\text { Considerate } \\ \text { Extent }\end{array}} \quad \begin{gathered}\frac{64.2}{\text { Very Great }} \\ \text { Extent }\end{gathered} \quad \frac{4.53}{\text { Mean }}$

D. Processes

Please respond to the following regarding the processes inside your team:

1. How often do people in your team

Never Rarely Sometimes Often Constantly Mean disagree about opinions regarding the work being done?

1.0

2. How much are personality conflicts evident in your team?

$\begin{array}{lll}1.0 & 17.9 & 48.0\end{array}$

5.649

4.1

3.17

3. How frequently are there conflicts about ideas in your team?

3.623.

33.0

8.6

3.6

4. How much tension is there among members in your team?

10.

5. My team's dealings with other teams go smoothly

6. My immediate supervisor attempts to resolve disagreements in a constructive manner

$$
4 .
$$

$4.1 \quad 10$.

$4.1 \quad 8.6$

$$
51.0
$$

3.1

$\underline{2.95}$

7. Our leader is hesitant about taking initiative in the group

7.2

\begin{tabular}{|c|c|c|c|c|c|c|c|}
\hline & & $\begin{array}{l}\text { Strongly } \\
\text { Disagree }\end{array}$ & $\begin{array}{l}\text { Slightly } \\
\text { Disagree }\end{array}$ & Neither & $\begin{array}{l}\text { Slightly } \\
\text { Agree }\end{array}$ & $\begin{array}{l}\text { Strongly } \\
\text { Agree }\end{array}$ & Mean \\
\hline & $\begin{array}{l}\text { Members are free to be assertive } \\
\text { about what they think and feel }\end{array}$ & 1.5 & 5.1 & 7.7 & 36.4 & 49.2 & 4.27 \\
\hline & $\begin{array}{l}\text { My team attempts to resolve } \\
\text { disagreements in a constructive } \\
\text { manner }\end{array}$ & 2.1 & 6.2 & 8.7 & 46.7 & 36.4 & 4.09 \\
\hline 10. & $\begin{array}{l}\text { When there's a problem, members } \\
\text { talk about it }\end{array}$ & 1.0 & 8.8 & 10.3 & 39.7 & 40.2 & 4.09 \\
\hline 11. & $\begin{array}{l}\text { Our leader fails to take necessary } \\
\text { action }\end{array}$ & 36.7 & 31.6 & 15.3 & 10.2 & 6.1 & 2.17 \\
\hline 12. & $\begin{array}{l}\text { There is good cooperation between } \\
\text { functions }\end{array}$ & 4.6 & 10.8 & 13.3 & 46.2 & 25.1 & 3.76 \\
\hline 13. & $\begin{array}{l}\text { Members are able to say what they } \\
\text { think }\end{array}$ & 1.5 & 6.2 & 6.7 & 36.9 & 48.7 & 4.25 \\
\hline 14. & $\begin{array}{l}\text { My immediate supervisor proposes a } \\
\text { reasonable approach to resolve } \\
\text { disagreements }\end{array}$ & 4.6 & 8.2 & 17.4 & 35.9 & 33.8 & 3.86 \\
\hline 1. & $\begin{array}{l}\text { There is good cooperation between } \\
\text { sites }\end{array}$ & 4.6 & 12.3 & 23.1 & 40.0 & 20.0 & 3.58 \\
\hline 16. & $\begin{array}{l}\text { Our leader lets others take away the } \\
\text { leadership of the group }\end{array}$ & 23.4 & 24.0 & 21.9 & 23.4 & 7.3 & 2.67 \\
\hline & $\begin{array}{l}\text { My team proposes a reasonable } \\
\text { approach to resolve disagreements }\end{array}$ & 2.6 & 4.2 & 19.9 & 47.6 & 25.7 & 3.90 \\
\hline
\end{tabular}

Please indicate the extent to which you agr 
18. There is good communication

\begin{tabular}{cccccc}
$\begin{array}{c}\text { Strongly } \\
\text { Disagree }\end{array}$ & $\begin{array}{c}\text { Slightly } \\
\text { Disagree }\end{array}$ & Neither & $\begin{array}{c}\text { Slightly } \\
\text { Agree }\end{array}$ & $\begin{array}{c}\text { Strongly } \\
\text { Agree }\end{array}$ & Mean \\
2.6 & 6.7 & 8.8 & 54.1 & 27.8 & $\underline{3.98}$ \\
\hline
\end{tabular}
together

E. Enabling Conditions

Please indicate the extent to which you agree or disagree with the following statements:

1. There is agreement about our priorities in our team

Strongly

Slightly

Disagree

Disagree

Neither

Slightly Strongly

$\begin{array}{llllll}5.1 & 15.4 & 12.3 & 40.0 & 27.2 & \end{array}$

2. We can count on the people in our team to perform their jobs proficiently

3. Team members always do what they say they will do

4. We have a shared understanding of what we are trying to accomplish

5. The people on our team are reliable in their work

$$
2.1
$$

$\begin{array}{llllll}3.1 & 8.8 & 10.9 & 42.5 & 34.7 & \end{array}$

$\begin{array}{llllll}2.1 & 3.6 & 9.3 & 41.5 & 43.5 & \underline{4.21}\end{array}$

6. There is an agreed way of getting the work done in our team

7. Team members believe that others on our team will follow through on their commitments

$\begin{array}{rrrrrr}2.1 & 4.2 & 9.9 & 50.3 & 33.5 & \underline{4.09} \\ 6.3 & 14.7 & 23.0 & 36.1 & 19.9 & \underline{3.49} \\ 6.8 & 17.7 & 18.2 & 34.9 & 22.4 & \underline{3.48} \\ 2.1 & 6.8 & 11.5 & 45.3 & 34.4 & \underline{4.03} \\ 3.7 & 13.7 & 16.8 & 43.2 & 22.6 & \underline{3.67} \\ 2.1 & 4.2 & 6.8 & 42.4 & 44.5 & \underline{4.23}\end{array}$

\section{F. Collaboration Structure}

Please indicate the extent to which you agree or disagree with the following statements:

1. Members have to obtain information

$\begin{array}{cccccc}\begin{array}{c}\text { Strongly } \\ \text { Disagree }\end{array} & \begin{array}{c}\text { Slightly } \\ \text { Disagree }\end{array} & \text { Neither } & \begin{array}{c}\text { Slightly } \\ \text { Agree }\end{array} & \begin{array}{c}\text { Strongly } \\ \text { Agree }\end{array} & \text { Mean } \\ 1.0 & 5.8 & 7.9 & 44.0 & 41.4 & \underline{4.19} \\ 22.8 & 23.3 & 23.8 & 21.2 & 8.8 & \underline{2.70} \\ & & & & & \\ 1.6 & 11.4 & 23.8 & 45.6 & 17.6 & \underline{3}\end{array}$
and advice from each other in order to complete their work

$\begin{array}{cccccc}\begin{array}{c}\text { Strongly } \\ \text { Disagree }\end{array} & \begin{array}{c}\text { Slightly } \\ \text { Disagree }\end{array} & \text { Neither } & \begin{array}{c}\text { Slightly } \\ \text { Agree }\end{array} & \begin{array}{c}\text { Strongly } \\ \text { Agree }\end{array} & \text { Mean } \\ 1.0 & 5.8 & 7.9 & 44.0 & 41.4 & \underline{4.19} \\ 22.8 & 23.3 & 23.8 & 21.2 & 8.8 & \underline{2.70} \\ 1.6 & 11.4 & 23.8 & 45.6 & 17.6 & \underline{3.66}\end{array}$

2. How much pay I receive depends almost entirely on how well I perform my job

3. My team forms alliances with people in different units at the company to work toward mutual objectives 
4. My contributions to this team are rewarded by the company

5. Each member of this team is held personally accountable for team results

5.2

17.1

24.4

38.9

14.5

3.40

6. My team maintains contacts with people in other parts of the company who can be a useful source of information, resources, and support

7. My pay level is determined by my individual job performance

8. Our team's work has measurable team outcomes

9. The members of our team change frequently

10. My immediate supervisor forms alliances with people in different units at the company to work toward mutual objectives

11. On this team, we share the responsibility for our deliverables

12. The contributions of each member to this team are valued by their subunit

11.9

43.0

35.8

4.03

13. My pay depends on the success of the team I work with

14. In order to complete our work, we have to obtain information and advice from each other

15. My immediate supervisor maintains contact with people in other parts of company who can be a useful source of information

$$
5.3
$$

$$
7.4
$$

16. Our team has quantifiable targets

17. Members of this team are rewarded commensurate with their contributions

8. Teams are rewarded in line with their performance here

$\begin{array}{lrrrrr}16.4 & 22.8 & 37.0 & 19.6 & 4.2 & \underline{2.72} \\ 19.6 & 24.9 & 31.2 & 19.6 & 4.8 & \underline{2.65}\end{array}$

\section{G. Resources and Work Environment}

1. The company has committed the resources required to do this work

2. It seems that everything is changing around here

$\begin{array}{crrrrr}\begin{array}{c}\text { Strongly } \\ \text { Disagree }\end{array} & \begin{array}{c}\text { Slightly } \\ \text { Disagree }\end{array} & \text { Neither } & \begin{array}{c}\text { Slightly } \\ \text { Agree }\end{array} & \begin{array}{c}\text { Strongly } \\ \text { Agree }\end{array} & \text { Mean } \\ 22.4 & 24.0 & 13.5 & 27.1 & 13.0 & \underline{2.84} \\ 2.1 & 8.4 & 22.5 & 31.4 & 35.6 & \underline{3.90} \\ 8.9 & 15.6 & 16.1 & 38.5 & 20.8 & \underline{3.47} \\ 2.1 & 4.1 & 17.1 & 34.2 & 42.5 & \underline{4.11}\end{array}$

3. We receive prompt technical assistance when our computer systems are not working

4. Many aspects of the company are changing at the same time 
5. We cannot count on continuity of the resources we need

6. We waste considerable time in doing our work because of information technology problems that are not fixed

$\begin{array}{rrrrrr}20.3 & 34.9 & 21.4 & 16.7 & 6.8 & \underline{2.55} \\ 5.7 & 11.9 & 22.3 & 36.3 & 23.8 & \underline{3.61} \\ 6.8 & 10.4 & 22.4 & 31.8 & 28.6 & \underline{3.65} \\ 6.3 & 14.8 & 21.7 & 41.3 & 15.9 & \underline{3.46} \\ 10.9 & 25.5 & 32.8 & 20.3 & 10.4 & \underline{2.94}\end{array}$

7. Priorities keep being changed

8. We have to fight to hold on to the resources we need

9. Company provides adequate information technology support

10. The people who use my work keep changing their requirements

\section{H. Satisfaction With Distributed Work}

Please indicate how satisfied you are with the following characteristics of distributed work:

1. Amount of travel

$$
\text { Very }
$$

\section{Dissatisfied}

Dissatisfied

Very
Neither Satisfied Satisfied

Mean

2. Flexibility

6.7

10.9

30.6

33.7

13.3

41.0

18.1

3. Gaining technology skills

2.6

14.4

20.0

42.6

37.9

4. Developing new relationships

3.6

10.8

21.6

47.4

20.5

5. Face to face social opportunities

6.2

$21.5 \quad 25.1$

34.9

16.5

3.46

6. Interruptions to personal life

17.1

37.8

29.5

12.3

$\underline{4.08}$

7. Visibility of my work

17.9

25.1

40.5

3.64

8. Technological dependence

2.1

6.8

39.8

42.4

3.62

3.26

3.19

\begin{tabular}{ll}
9.3 & 3.19 \\
9.2 & 3.27 \\
\hline
\end{tabular}

$8.9 \quad 3.49$

\section{Personal Characteristics}

Please indicate the extent to which the following describe you personally:

1. It is inappropriate to express negative

$\begin{array}{cccccc}\begin{array}{c}\text { Strongly } \\ \text { Disagree }\end{array} & \begin{array}{c}\text { Slightly } \\ \text { Disagree }\end{array} & \text { Neither } & \begin{array}{c}\text { Slightly } \\ \text { Agree }\end{array} & \begin{array}{c}\text { Strongly } \\ \text { Agree }\end{array} & \text { Mean } \\ 9.8 & 26.3 & 17.0 & 31.4 & 15.5 & \underline{3.16} \\ 0 & 1.0 & 2.6 & 42.3 & 54.1 & \underline{4.49} \\ 0 & 0.5 & 2.6 & 49.2 & 47.7 & \underline{4.44} \\ 6.7 & 10.3 & 32.0 & 31.4 & 19.6 & \underline{3.47} \\ & & & & & \\ 6.7 & 16.6 & 18.1 & 36.8 & 21.8 & \underline{3.50} \\ 7.3 & 15.0 & 18.1 & 40.9 & 18.7 & \underline{3.49}\end{array}$

2. I try to investigate an issue with others to find a solution acceptable to all

3. I try to integrate my ideas with those of others to come up with a decision jointly

4. I am eager to tell outsiders that this is a good place to work

5. I am satisfied with the chances I have to do something that makes me feel good about myself as a person

6. I am satisfied with the chances I have to accomplish something worthwhile 


\section{J. Attitudes}

Please indicate the extent to which you agree or disagree with the following statements:

1. I believe I am fairly paid compared

.

$\begin{array}{lllccc}\text { Strongly } & \text { Slightly } & & \text { Slightly } & \text { Strongly } & \\ \text { Disagree } & \text { Disagree } & \text { Neither } & \text { Agree } & \text { Agree } & \text { Mean }\end{array}$

to my peers at the company who are at equivalent job levels and who are equivalently skilled

$\begin{array}{rrrrrr}13.9 & 23.2 & 24.7 & 25.8 & 12.4 & \underline{2.99} \\ 12.3 & 28.7 & 17.9 & 28.2 & 12.8 & \underline{3.01} \\ 8.2 & 14.4 & 21.6 & 41.2 & 14.4 & \underline{3.39} \\ 6.1 & 12.7 & 15.7 & 47.7 & 17.8 & \underline{3.58} \\ 16.8 & 20.4 & 21.4 & 27.0 & 14.3 & \underline{3.02}\end{array}$

6. I am satisfied with the progress I have made toward meeting my overall career goals

7. I plan to look outside the company for a new job within the next year

8. I am satisfied with the chances I have to accomplish something worthwhile

9. I believe I am fairly paid compared to my peers in other companies who are at equivalent job levels and who are equivalently skilled

10. I have very little control over the hours I am expected to work

11. My job enables me to use all my capabilities

$\begin{array}{rrrrrr}10.7 & 24.4 & 17.8 & 36.5 & 10.7 & \underline{3.12} \\ 17.4 & 18.5 & 31.8 & 19.5 & 12.8 & \underline{2.92} \\ 6.7 & 15.9 & 23.1 & 41.0 & 13.3 & \underline{3.38}\end{array}$

12. I am satisfied with my current salary

13. I am satisfied with the progress I have made toward meeting my goals for advancement

14. I am satisfied with the chances I have to do something that makes me feel good about myself as a person

15. The company has a good process for mentoring employees

16. It is likely that I will quit my job in the next twelve months

1

26.9

15.9

32.8

27.2

$10.8 \quad 3.06$

$\begin{array}{rrrrrr}7.3 & 15.6 & 20.3 & 45.3 & 11.5 & \underline{3.38} \\ 24.0 & 28.1 & 29.7 & 13.5 & 4.7 & \underline{2.47} \\ 26.6 & 22.4 & 29.2 & 13.0 & 8.9 & \underline{2.55} \\ 13.5 & 26.0 & 20.3 & 29.2 & 10.9 & 2.98\end{array}$

17. My work enables me to use my full range of expertise

18. My family/friends dislike how often I am preoccupied with my work while at home

19. In general, I like working here

20. The company has a good process for identifying employees' development needs

1. On the job I have so much work to do that it takes away from my personal interests 
22. I am satisfied with the chances I have

$\begin{array}{lllccc}\text { Strongly } & \text { Slightly } & & \text { Slightly } & \text { Strongly } & \\ \text { Disagree } & \text { Disagree } & \text { Neither } & \text { Agree } & \text { Agree } & \text { Mean }\end{array}$
to learn new things at work

\begin{tabular}{llllll}
4.2 & 17.8 & 20.9 & 42.4 & 14.7 & \\
\hline
\end{tabular}

K. Demographics

1. How long have you been with the company?

$7.4 \% 1$ year or less

$16.3 \% \quad 2-3$ years

$40.1 \% \quad 4-5$ years

$\underline{36.1 \%} 6$ or more years

2. How many teams/projects are you involved with? 3.03 (number of teams)

3. How many of these operate primarily distributed? 2.20 (number of distributed teams)

4. How many years of experience do you have working on distributed teams? $\quad 5.77$ years

5. What is the level of your education? (Please indicate highest completed.)

$2.0 \%$ High school or equivalent

$3.5 \%$ Some college or technical training, but no degree, beyond high school (1-3 years)

$2.0 \%$ Associate's Degree or equivalent (2-year degree)

$\underline{44.1 \%}$ Graduated from 4-year college (BA, BS, or other Bachelor's degree)

$41.6 \%$ Master's degree or equivalent

$6.9 \%$ Doctorate degree or equivalent

6. How old were you on your last birthday?

$0 \% 19$ years or younger

$2.0 \% 20$ to 24

$13.3 \% 25$ to 29

$24.1 \% 30$ to 34

$23.2 \% 35$ to 39

$16.3 \%$ to 44

$10.8 \% \quad 45$ to 49

$7.4 \% 50$ to 54

$2.5 \% 55$ to 59

$0.5 \% \quad 60$ years or older

7. Country you live in now:

Canada (0.5\%); Czech Republic (11.8\%); France (4.9\%); India (10.3\%); Norway (1.0\%); United States $(67.2 \%)$

8. Country/region you were born in:

$1.0 \%$ Africa and Middle East

$29.7 \%$ Asia

27.2\% Europe and Russia (including United Kingdom)

$1.0 \%$ Latin America (including Central and South America, and Mexico)

$40.1 \%$ United States and Canada

$1.0 \%$ Other:

9. Is English your first or native language? $46 \%$ Yes

If no, do you speak English fluently? $\underline{96 \%}$ Yes 


\section{References}

Appelbaum, E., and R. Batt. 1994. The new American workplace: Transforming work systems in the U.S. Ithaca, New York: Cornell ILR Press.

Bell, B. S., and S. W. J. Kozlowski. 2002. A typology of virtual teams: Implications for effective leadership. Group and Organization Management 27 (1): 14-49.

Bulow, J., and L. H. Summers. 1986. A theory of dual labor markets with application to industrial policy, discrimination, and Keynesian unemployment. Journal of Labor Economics 4 (3) Part 1:376-414.

Campion, M. A., G. J. Medsker, and A. C. Higgs. 1993. Relations between work group characteristics and effectiveness: Implications for designing effective work groups. Personnel Psychology 46 (4): 823-50.

Campion, M. A., E. M. Papper, and G. J. Medsker. 1996. Relations between work team characteristics and effectiveness: A replication and extension. Personnel Psychology 49 (2): 429-52.

Cappel, J. J., and J. C. Windsor. 2000. Ethical decision making: A comparison of computer-supported and face-to-face group. Journal of Business Ethics 28 (2): 95-107.

Cappelli, P., and D. Neumark. 2001. Do high performance work practices improve establishment-level outcomes? Industrial and Labor Relations Review 54 (4): 737-75.

Cohen, S. G., and D. Bailey. 1997. What makes teams work: Group effectiveness research from the shop floor to the executive suite. Journal of Management 23 (3): 239-90.

Driskell, J. E., P. H. Radtke, and E. Salas. 2003. Virtual teams: Effects of technological mediation on team performance. Group Dynamics: Theory, Research, and Practice 7 (4): 297-323.

Gibbons, R. 2003. Team theory, garbage cans and real organizations: Some history and prospects of economic research on decision-making in organizations. Industrial and Corporate Change 12 (4): 753-87.

Gibson, C. B., and S. G. Cohen. 2003. Virtual teams that work: Creating conditions for virtual team effectiveness. San Francisco, CA: Jossey-Bass.

Gladstein, D. 1984. A model of task group effectiveness. Administrative Science Quarterly 29 (4): 499-517.

Glaser, B. G., and A. L. Strauss. 1967. The discovery of grounded theory: Strategies for qualitative research. Chicago: Aldine.

Graetz, K. A., E. Boyle, C. Kimble, P. Thompson, and J. Garloch. 1998. Information sharing in face-to-face, teleconferencing, and electronic chat groups. Small Group Research 29 (6): 714-43.

Guzzo, R. A., and M. W. Dickson. 1996. Teams in organizations: Recent research on performance and effectiveness. Annual Review of Psychology 47:307-38.

Hackman, J. R. 1987. The design of work teams. In Handbook of organizational behavior ed. J. W. Lorsch, 315-42. Englewood Cliffs, NJ: Prentice-Hall.

Hackman, J. R., and G. R. Oldham. 1980. Work redesign. Reading, MA: AddisonWesley.

Hiltz, S. R., K. Johnson, and M. Turoff. 1986. Experiments in group decision making: Communication process and outcome in face-to-face versus computerized conferences. Human Communication Research 13 (2): 225-52.

Ichniowski, C., K. Shaw, and G. Prennushi. 1997. The effects of human resource management practices on productivity. American Economic Review 87 (3): 291-313. 
Janz, B. D., J. A. Colquitt, and R. A. Noe. 1997. Knowledge worker team effectiveness: The role of autonomy, interdependence, team development, and contextual support variables. Personnel Psychology 50 (4): 877-904.

Keller, R. T. 1986. Predictors of the performance of project groups in R\&D organizations. Academy of Management Journal 29 (4): 715-26.

Kochan, T. A., C. Ichniowski, D. Levine, C. Olson, and G. Strauss. 1996. What works at work: A critical review. Industrial Relations 35 (3): 299-333.

Krishnan, R., X. Martin, and N. G. Noorderhaven. 2006. When does trust matter to alliance performance? Academy of Management Journal 49 (5): 894-917.

Langfred, C. W. 2007. The downside of self-management: A longitudinal study of the effects of conflict on trust, autonomy, and task interdependence in selfmanaging teams. Academy of Management Journal 50 (4): 885-900.

Lawler, Edward E. III. 2003. Treat people right. San Francisco, CA: Jossey-Bass.

Lawrence, P. R., and J. W. Lorsch. 1967. Organization and environment. Boston, MA: Harvard Business School Press.

Lee, T. W. 1999. Using qualitative methods in organizational research. Thousand Oaks, CA: SAGE.

Marschak, J., and R. Radner. 1972. Economic theory of teams. New Haven, CT: Yale University Press.

Marshall, C., and G. B. Rossman. 1995. Designing qualitative research, Second edition. Thousand Oaks, CA: SAGE.

Martins, L. L., L. L. Gilson, and M. T. Maynard. 2004. Virtual teams: What do we know and where do we go from here? Journal of Management 30 (6): 805-35.

Mayer, R. C., J. H. Davis, and F. D. Schoorman. 1995. An integrative model of organizational trust. Academy of Management Review 20 (3): 709-34.

Mayer, R. C., and M. B. Gavin. 2005. Trust in management and performance: Who minds the shop while the employees watch the boss? Academy of Management Journal 48 (5): 874-88.

McDonough, E. F., III, K. B. Kahn, and G. Barczak. 2001. An investigation of the use of global, virtual, and collocated new product development teams. The Journal of Product Innovation Management 18 (2): 110-20.

Mishra, A. K., and G. M. Spreitzer. 1998. Explaining how survivors respond to downsizing: The roles of trust, empowerment, justice, and work redesign. Academy of Management Journal 23 (3): 567-88.

Mohrman, S. A., S. G. Cohen, and A. M. Mohrman, Jr. 1995. Designing team-based organizations: New forms for knowledge work. San Francisco, CA: Jossey-Bass.

Paxson, C. H., and N. Sicherman. 1996. The dynamics of dual-job holding and job mobility. Journal of Labor Economics 14 (3): 357-93.

Prendergast, C. 1999. The provision of incentives in firms. Journal of Economic Literature 37 (1): 7-63.

Radner, R. 1992. Hierarchy: The economics of managing. Journal of Economic Literature 30 (3): 1382-1415.

Rousseau, D. M., S. B. Sitkin, R. S. Burt, and C. Camerer. 1998. Not so different after all: A cross-discipline view of trust. Academy of Management Review 23 (3): 393-404.

Saparito, P. A., C. C. Chen, and H. J. Sapienza. 2004. The role of relational trust in bank-small firm relationships. Academy of Management Journal 47 (3): 400-10.

Saphiere, D. M. H. 1996. Productive behaviors of global business teams. International Journal of Intercultural Relations 20 (2): 227-59.

Schmidt, J. B., M. M. Montoya-Weiss, and A. P. Massey. 2001. New product development decision-making effectiveness: Comparing individuals, face-to-face teams, and virtual teams. Decision Sciences 32 (4): 575-600. 
Schoorman, F. D., R. C. Mayer, and J. H. Davis. 2007. An integrative model of organizational trust: Past, present, and future. Academy of Management Review 32 (2): $344-54$.

Schor, J. B. 1991. The overworked American: The unexpected decline of leisure. New York: Basic Books.

Shapiro, C., and J. E. Stiglitz. 1984. Equilibrium unemployment as a worker discipline device. American Economic Review 74 (3): 433-44.

Strauss, A. L. 1987. Qualitative analysis for social scientists. New York: Cambridge University Press.

Strauss, S. G., and J. E. McGrath. 1994. Does the medium matter? The interaction of task type and technology on group performance and member reactions. Journal of Applied Psychology 79 (1): 87-97.

Valacich, J. S., J. F. George, J. F. Nunamaker, Jr., and D. R. Vogel. 1994. Physical proximity effects on computer-mediated group idea generation. Small Group Research 25 (1): 83-104.

Yin, R. K. 2003. Case study research: Design and methods, third edition (Applied social sciences research methods series, v.5). Thousand Oaks, CA: SAGE. 